Article

\title{
Investigating Virus-Host Interactions in Cultured Primary Honey Bee Cells
}

\author{
Alexander J. McMenamin ${ }^{1,2,3,+}$, Fenali Parekh ${ }^{1,2,3,+}$, Verena Lawrence ${ }^{1,3}$ and Michelle L. Flenniken ${ }^{1,2,3, *}$ \\ 1 Department of Plant Sciences and Plant Pathology, Montana State University, Bozeman, MT 59717, USA; \\ alexmcmenamin2@gmail.com (A.J.M.); fenali10@gmail.com (F.P.); verena.cml@gmail.com (V.L.) \\ 2 Department of Microbiology and Cell Biology, Montana State University, Bozeman, MT 59717, USA \\ 3 Pollinator Health Center, Montana State University, Bozeman, MT 59717, USA \\ * Correspondence: michelle.flenniken@montana.edu; Tel.: +1-406-994-7229 \\ + These authors contributed equally to this work.
}

Citation: McMenamin, A.J.; Parekh, F.; Lawrence, V.; Flenniken, M.L. Investigating Virus-Host Interactions in Cultured Primary Honey Bee Cells. Insects 2021, 12, 653. https:/ / doi.org/10.3390/insects12070653

Academic Editors: Mike J. Goblirsch and Wayne B. Hunter

Received: 29 June 2021

Accepted: 13 July 2021

Published: 17 July 2021

Publisher's Note: MDPI stays neutral with regard to jurisdictional claims in published maps and institutional affiliations.

Copyright: (c) 2021 by the authors. Licensee MDPI, Basel, Switzerland. This article is an open access article distributed under the terms and conditions of the Creative Commons Attribution (CC BY) license (https:/ / creativecommons.org/licenses/by/ $4.0 /)$.
Simple Summary: Honey bees are eusocial insects that live in colonies comprised of $\sim 30,000$ individuals. They are the primary pollinators of plants that produce fruits, nuts, and vegetables. High annual losses of honey bee colonies have made it challenging for beekeepers to provide enough colonies to meet the demand for pollination services. Multiple stressors, including viruses, contribute to colony deaths. To better understand viral pathogenesis and bee antiviral defense mechanisms, we obtained primary cells from honey bee larvae and pupae, maintained them in culture, and infected them with a panel of viruses. We determined that larval hemocytes, which are primary immune cells, support replication of a honey bee virus (sacbrood virus) and a model virus (Flock House virus). Similarly, we determined that mixed cell populations derived from honey bee pupae support replication of sacbrood virus, Flock House virus, and another honey bee virus (deformed wing virus). Evaluation of the host cellular level response to infections with each of these viruses revealed unique expression profiles of three immune genes. In summary, this study demonstrates the utility of honey bee primary cell cultures to investigate the impacts of virus infection on honey bees at the cellular level, which in turn affects individual bee and colony health.

Abstract: Honey bee (Apis mellifera) health is impacted by viral infections at the colony, individual bee, and cellular levels. To investigate honey bee antiviral defense mechanisms at the cellular level we further developed the use of cultured primary cells, derived from either larvae or pupae, and demonstrated that these cells could be infected with a panel of viruses, including common honey bee infecting viruses (i.e., sacbrood virus (SBV) and deformed wing virus (DWV)) and an insect model virus, Flock House virus (FHV). Virus abundances were quantified over the course of infection. The production of infectious virions in cultured honey bee pupal cells was demonstrated by determining that naïve cells became infected after the transfer of deformed wing virus or Flock House virus from infected cell cultures. Initial characterization of the honey bee antiviral immune responses at the cellular level indicated that there were virus-specific responses, which included increased expression of bee antiviral protein-1 (GenBank: MF116383) in SBV-infected pupal cells and increased expression of argonaute-2 and dicer-like in FHV-infected hemocytes and pupal cells. Additional studies are required to further elucidate virus-specific honey bee antiviral defense mechanisms. The continued use of cultured primary honey bee cells for studies that involve multiple viruses will address this knowledge gap.

Keywords: honey bee; Apis mellifera; primary cell culture; insect antiviral defense; honey bee viruses; RNA viruses; insect viruses

\section{Introduction}

All organisms are infected by viruses, which are obligate intracellular pathogens that rely on host cell machinery to replicate. In turn, hosts evolve mechanisms to prevent and/or 
limit virus infections. To investigate host-virus interactions at the cellular and molecular levels, scientists rely extensively on cell cultures, including immortalized cell lines and primary cells [1-3]. Cultured cells are amenable to techniques that augment or silence gene expression (e.g., transfection of plasmids and nucleic acids) and are thus invaluable to studies aimed at elucidating biological mechanisms. Furthermore, cell cultures are also utilized to produce pure virus stocks, which are important for experimentation and vaccine production [4-7]. In spite of their utility and importance, robust cell culture systems are not available for many non-model organisms, including honey bees (Apis mellifera). While approximately 1000 cell lines have been derived from insect tissues, including 19 hymenopteran cell lines (the insect order that includes bees, ants, and wasps), only one immortalized honey bee cell line, AmE-711, has been established [8-10].

The development of additional tools to understand honey bee host-virus interactions at the cellular level is critical for determining the impact of virus infections at the individual bee and colony levels and may ultimately result in the development of strategies that reduce the number of virus-associated honey bee colony deaths. Honey bee colony losses averaged 38\% annually from 2010 to 2018, in part due to viral infections [11-19]. Honey bees are cosmopolitan agricultural pollinators that are impacted by numerous stressors, including agrochemicals, lack of quality forage and habitat, colony and habitat management, the Varroa destructor mite, and pathogens including bacteria, fungi, trypanosomatids, and viruses [20-31]. The largest group of honey-bee-infecting pathogens are small RNA viruses (reviewed in [23,32]). The list of honey bee-infecting and honey-bee-associated viruses is ever growing, in part due to virus discovery efforts aided by the increased use of high throughput sequencing of either total RNA or virally enriched RNA sample sequencing [33-41] (reviewed in [23,24]). The most ubiquitous and well-studied honey-beeassociated viruses include acute bee paralysis virus [42], black queen cell virus [43], chronic bee paralysis virus [44,45], deformed wing virus [46,47], Israeli acute paralysis virus [48], Kashmir bee virus [49], sacbrood virus [50], and the Lake Sinai virus group [40,51]. Viral infections can result in various symptoms, from paralysis to deformity or shortened lifespan, but individual bees can also harbor high viral loads ( 100 billion copies per bee) and show no apparent symptoms [40,52-54].

The Iflaviridae family comprises several arthropod-associated viruses, including two honey-bee-infecting viruses (i.e., sacbrood virus and deformed wing virus) [55-58]. Sacbrood virus (SBV) infects both larvae and adults and is likely spread throughout a colony by adult nurse bees that ingest infected larvae, develop SBV infections, including in their hypopharyngeal glands, and transmit the virus to new larvae by feeding them contaminated brood food [59,60]. While SBV may shorten the lifespan of adult bees, it is most pathogenic to young larvae, which become discolored and yellow as the infection progresses. As the infected larva develops, its cuticle becomes leathery, which prevents molting, and fluid builds up, creating a saclike appearance [58]. Concurrent with larvae production, SBV prevalence typically peaks in honey bee colonies in the spring and summer months [40,61-64]. Deformed wing virus (DWV) infects both developing and adult bees. Infection of larvae or pupae can cause wing deformities, likely due to infection of nascent wing buds [65-68]. DWV infection of adults is associated with short, bloated abdomens, shortened life span, and precocious foraging, while reducing total foraging time [69-72]. Infection of the brain is sometimes associated with increased aggression, reduced associative learning, and downregulation of genes associated with neuronal signaling, suggesting a dysregulation of normal brain function [73-75]. Deformed wing virus can be acquired vertically through contamination of eggs via infected ovarian tissue or DWV-positive semen or horizontally via mating, contaminated food (i.e., brood food or pollen), trophallaxis, pupal cannibalism, or the bite of a Varroa destructor mite [76-81] (reviewed in [82]). Varroa mites, which primarily feed on the honey bee fat body, serve as passive and/or replication-competent viral vectors [66,83-87]. DWV strains include DWV-A, DWV-B/VDV-1, which share approximately $84 \%$ nucleotide identity, and DWV-C, as well as recombinant viruses [88-93]. DWV is one of the most well-studied honey bee viruses, and high DWV levels, coupled with mite 
infestation, are associated with honey bee colony losses [94-98]. Recent development of DWV infectious clones will further our understanding of this virus and its interactions with bee and mite hosts $[65,78,99]$. In the absence of infectious clones, scientists have utilized crude virus preparations obtained from infected honey bees, including at the larval and pupal stages [10,68,86,100-104].

Model viruses, including Sindbis virus and Flock House virus, have also been utilized to investigate honey bee antiviral defense mechanisms [4,105-109]. These viruses are relatively easily to propagate and purify and are important tools for investigating antiviral response across a range of different species, including honey bees, fruit flies, and mosquitos [4,105-112]. Flock House virus (FHV) is a small, nonenveloped, icosahedral insect virus in the Nodaviridae family. FHV is genetically and structurally well-characterized and has been extensively utilized in studies aimed at understanding basic viral processes, including genome replication and virion assembly [113-120]. FHV is also a valuable model virus for investigating insect antiviral immunity. Although FHV was originally isolated from grass grubs (Costelytra Zealandica), it infects a range of insects, including mosquitoes, fruit flies, tsetse flies, and honey bees [105,106,110,111,121,122]. To counteract the host immune defense systems, several invertebrate viruses have evolved viral suppressors of RNAi (VSR), and RNA-based strategies (i.e., decoy molecules or miRNAs) (reviewed in [123]). Suppressors of RNAi are virus-encoded proteins that either inhibit the RNAi machinery (e.g., Dicer, Argonaute) or bind viral RNAs and protect them from Dicer-mediated cleavage or loading onto the RNA-induced silencing complex (RISC) (reviewed in [124-126]). The FHV-encoded B2 protein is a VSR that suppresses RNAi-mediated virus silencing by binding both long double-stranded RNAs (dsRNAs) and short interfering RNAs (siRNAs). Binding of FHV-B2 to long dsRNA, including viral replicative intermediates, protects them from cleavage, whereas high affinity binding of B2 to siRNAs prevents their incorporation into RISC, both of which result in suppression of the host RNAi response [113,127,128].

Similar to other insects, honey bee antiviral defense involves numerous processes and pathways, including autophagy, endocytosis, apoptosis, eicosanoid signaling, melanization, and the Toll and Imd (Immune Deficiency) pathways involving NF- $\mathrm{KB}$ (Nuclear Factor $\mathrm{kB}$ ) homologues Dorsal and Relish, JAK/STAT (Janus Kinase/Signal Transducer and Activator of Transcription), JNK (c-Jun N-terminal kinase), MAPK (Mitogen-Activated Protein Kinases), and RNA interference (RNAi) pathways (reviewed in [23,129-131]). RNA interference is a sequence-specific post-transcriptional gene silencing mechanism that is induced upon recognition of long double-stranded RNA (dsRNA) (endogenous or virally derived) by the endonuclease Dicer. Dicer cleaves dsRNA into 21-22 bp doublestranded short interfering RNAs (siRNAs). Then, in a process mediated by heat shock proteins, a single strand, called the guide strand is retained by Argonaute-2, within the RNA-induced silencing complex (RISC) [132,133]. RISC surveils the cell, binds RNA complementary to the guide strand, and cleaves it [108,112,124,130,131,134-139]. In honey bees and bumble bees, dsRNA, a virus-associated molecular pattern, also induces a nonsequence-specific antiviral immune response that limits virus infections [107-109,140-144]. To date, investigations of bee antiviral defense have been performed primarily in pupae and adult bees [95,96,101,105-109,138-143,145-150] (reviewed in [23,129]). Further development and use of honey bee cell cultures will enable more mechanistic studies of bee virology and immunology.

There is only one immortalized honey bee cell line, AmE-711, which was established from honey bee embryonic tissue [9] (reviewed in [8]). This cell line was used to study the dynamics of several co-infecting honey-bee-infecting viruses, including sacbrood virus (SBV), deformed wing virus (DWV), Israeli acute paralysis virus (IAPV), black queen cell virus (BQCV), and Kashmir bee virus (KBV) [10]. In that study, AmE-711 cells were inoculated with a mixed virus preparation that included varying levels of SBV, DWV, IAPV, and BQCV. In inoculated cells, IAPV outcompeted SBV, DWV, and BQCV; however, when cells were infected with a different inoculum that contained KBV, SBV, IAPV, and BQCV, KBV outcompeted all other viruses, including IAPV [10]. While an important step towards 
the development of immortalized honey bee cell lines, AmE-711 has a long doubling time, is difficult to maintain in other labs, and it is persistently infected with DWV [10]. Therefore, the use of non-honey-bee cells lines, including the Lepidopteran hemocytic cell line (P1), to study honey-bee-infecting viruses, including DWV, have been explored and will likely serve as an important tool for investigating bee viruses at a cellular level $[8,151]$. While immortalized cell cultures provide a convenient and consistent tool, they often do not fully recapitulate in situ biology. For example, the immune response that AmE-711, a honey bee fibroblast-type cell line, mounts against viruses may not represent the immune response in other honey bee tissues or cell types (i.e., fat body, endothelium, or hemocytes).

Primary honey bee cell cultures derived from different tissues provide a useful alternative to immortalized cell lines for the study of basic honey bee virology and immunology (reviewed in [152]). There are several advantages and disadvantages associated with the use of either immortalized cell lines or primary cells. For example, primary cultures may harbor preexisting infections, while immortalized cells may be persistently infected; therefore, it is best to carry out pathogen testing to ensure that the results obtained are not impacted by other infections [153-160]. Beneficial features of tissue-derived primary cell cultures include that they can contain diverse cell types or be enriched for one cell type. In addition, they can be generated from pooled tissue samples to control for the inter-individual variability associated with whole-animal experiments. Primary cell cultures that represent multiple individuals may be particularly important for generating robust data that is representative of outbred honey bee colonies comprising individuals from numerous unique patrilines. Primary cell cultures established from whole pupae, with differentiated head, thorax, and abdomen body segments, likely include numerous adipocytes and epithelial cells as well as more specialized cells including neurons and muscle cells. These mixed cell cultures may be beneficial for investigating virus-tropism and intercellular signaling in response to virus infection. Similarly, the establishment and use of primary cell cultures from specific tissues or cell types facilitates a more precise mechanistic-level understanding of host-virus interactions [3,161,162]. Hemocytes are the primary insect immune cells that phagocytose or encapsulate pathogens. There are several subtypes of hemocytes, which are characterized morphologically, histochemically, and/or functionally. These include prohemocytes, granulocytes, plasmatocytes, spherulocytes, and oenocytoids, which may be further distinguished based on functional diversity [163]. Honey bee hemocytes also exhibit functional and morphological heterogeneity. The majority of circulating phagocytic cells in bee larvae are granulocytes, whereas plasmatocytes are more prevalent in adults $[164,165]$. There may be additional infection-induced cell types not yet described, like lamellocytes in Drosophila melanogaster, which are induced upon infestation by a parasitoid wasp [166]. In addition to their heterogeneity in phagocytic ability, honey bee hemocytes differ in their expression of hemolectin, which is associated with an encapsulation response of foreign bodies [167]. While recent studies in Drosophila melanogaster demonstrate that hemocytes play a role in systemic antiviral immune response, the potential for hemocytes to be infected by viruses or the extent to which they may contribute to honey bee antiviral immunity is not known [96,163,168-171].

To investigate honey bee antiviral defense mechanisms at the cellular level, we further developed the use of cultured primary cells, derived from either larvae or pupae, and demonstrated that these cells could be infected with a panel of viruses, including common honey bee infecting viruses (i.e., SBV and DWV) and a model virus (FHV). Specifically, hemocytes obtained from stage L4-L5 honey bee larvae supported infection and replication of SBV and FHV. Virus replication was verified via detection of the replicative intermediate of both viruses using negative-strand-specific reverse transcription (RT), followed by polymerase chain reaction (PCR), and using quantitative PCR (qPCR) to demonstrate increased virus abundance over an infection time course. Mixed cell populations derived from purple-eyed honey bee pupae supported replication of SBV, DWV, and FHV. Virus replication was verified via negative-strand-specific RT-PCR and qPCR. Peak virus abundance was observed at $96 \mathrm{~h}$ post-infection (hpi) for SBV and DWV, while virus abundance 
peaked at 72 hpi for FHV. Furthermore, the production of infectious virions in cultured honey bee pupal cells was demonstrated by determining that naïve cells became infected after the transfer DWV or FHV infected cell culture material. Initial characterization of the honey bee antiviral immune responses mounted against SBV, DWV, and FHV at the cellular level indicate varying virus-specific responses, including increased expression of bee antiviral protein-1 (GenBank: MF116383) in SBV-infected pupal cells and increased expression of argonaute-2 and dicer-like in FHV-infected hemocytes and pupal cells [107,172]. Additional studies utilizing primary honey bee cell cultures and multiple viruses will help elucidate virus-specific antiviral defense mechanisms.

\section{Materials and Methods}

\subsection{Honey Bee Colonies}

Packages ( $1.5 \mathrm{~kg}$ of worker bees and a mated queen) of Carniolan honey bees (Apis mellifera carnica) were purchased from a commercial producer in Montana and installed in Langstroth hives at Montana State University, Bozeman, MT, USA. Colonies were maintained using standard apicultural practices, including bi-monthly Varroa destructor mite checks by the sugar roll method and treatment for mites with Mite Away Quick Strips (Nature's Own Design Apiary Products, Frankford, ON, Canada) when mite infestation was evaluated to be greater than $3 \%$ (3 mites per 100 bees $[173,174])$.

\subsection{Honey Bee Cell Cultures}

\subsubsection{Hemocytes}

Three days before experiments using primary honey bee hemocytes were performed, frames of brood with a lot of 4 th and 5th instar larvae (L4-L5) were brought to the laboratory and maintained in a humidified incubator at $28{ }^{\circ} \mathrm{C}$. Larvae that fell out of their cells were caught in a glass dish and collected in batch the next morning. After collection, larvae were surface-sterilized for $3 \mathrm{~min}$ in $0.6 \%$ hypochlorite (dilute bleach), followed by $3 \mathrm{~min}$ in $70 \%$ ethanol, and then briefly washed in sterile water for injection (Gibco) in a biological safety cabinet (Class II type A/B3, Nuaire). Larvae were placed into $200 \mu \mathrm{L}$ of WH2 media (pH 6.4, 150 mL Schneider's insect medium, SIGMA cat\# S0146; 200 mL 0.06M LHistidine, SIGMA cat\# H5659; 50 mL heat-inactivated fetal bovine serum, Life Technologies cat\# 16000044; 15 mL CMRL medium, Gibco cat\# 11530-037; 5 mL Hank's balanced salts, SIGMA cat\# H9394; 2 mL insect media supplement, SIGMA cat\# I7267), supplemented with $1 \times$ penicillin/streptomycin (ThermoFisher, cat\# 15070063), 10 at a time [33,175]. Sterile 18guage needles were used to wound larvae on the lateral cuticle of the abdomen. Each larva was wounded once on each side and exsanguinated directly into the media. Care was taken to minimize fat body release from the carcass to produce cultures with minimal adipocyte contamination (Supplemental Figure S1). Hemocytes were pooled in $15 \mathrm{~mL}$ conical tubes (Falcon, Corning) until enough were collected for each experiment. Hemocytes were then seeded in vacuum gas plasma treated polystyrene 48 -well plates (Falcon, Corning). On average, six larvae provided enough hemocytes $\left(\sim 1 \times 10^{5}\right.$ cells per well) for five wells on a 48-well plate.

To test for virus association with carcasses versus hemocytes, an independent set of larvae was obtained from two different colonies, and sterile 18-guage needles were used to wound individual larva $(n=37)$ on the lateral cuticle of the abdomen. Each larva was wounded one on each side and exsanguinated. Hemolymph was directly collected by pipetting (approximately $40 \mu \mathrm{L}$ ). Hemolymph was diluted with $100 \mu \mathrm{L}$ WH2 media; then, hemocytes were pelleted by centrifuging at $1000 \times g$ for $10 \mathrm{~min}$. Supernatant was removed, and hemocytes were suspended in $100 \mu \mathrm{L}$ WH2 media. Then, $800 \mu \mathrm{L}$ of TRIzol ${ }^{\circledR}$ reagent (Invitrogen) was added to the hemocytes, and they were stored at $-80^{\circ} \mathrm{C}$ until RNA extraction. 


\subsubsection{Pupal Cells}

Two days prior to honey bee pupal cell experiments, a brood frame containing purpleeyed pupae was brought into the lab. Fine-point, curved-tip forceps (Bioquip) were used to carefully remove the wax capping from pupae. Wide-tip, featherweight forceps (Bioquip) were used to gently grasp pupae between the eyes to remove them from the wax comb cells in which they develop. Pupae were incubated at $28^{\circ} \mathrm{C}$ overnight in 12 -well plates, and wounded (i.e., melanized) pupae were discarded. Primary cells were harvested from surface-sterilized honey bee pupae in a biosafety cabinet (Class II type A/B3, Nuaire). Surface sterilization was carried out in a sterile polystyrene petri dish $(100 \mathrm{~mm} \times 15 \mathrm{~mm}$, Fisher), in which pupae were swirled in $0.6 \%$ hypochlorite solution (diluted bleach) for $3 \mathrm{~min}, 70 \%$ ethanol for $3 \mathrm{~min}$, and briefly in sterile water for injection (Gibco). In groups of two, pupae were dissected into head, thorax, and abdomen segments in $2 \mathrm{~mL} \mathrm{WH2}$ medium in a $47 \mathrm{~mm}$ dish using sterile 18-gauge needles to vigorously disturb tissues and release cells into the medium [175]. The media containing the cells was then transferred to a $50 \mathrm{~mL}$ conical tube, and cells from individual pupa $\left(\sim 24 \times 10^{6}\right.$ cells $)$ were pooled. Cell suspensions with approximately $10^{6}$ cells per $300 \mu \mathrm{L}$ were plated into each well of a 48 -well plate and incubated at room temperature overnight before infection.

\subsection{Virus Preparation and Infection}

\subsubsection{Sacbrood Virus}

A stock of sacbrood virus was prepared from five symptomatic larvae, which were homogenized in $10 \mathrm{mM}$ Tris ( $\mathrm{pH} 7.5)$ using a sterile steel ball $(5 \mathrm{~mm})$ in a $2 \mathrm{~mL}$ microcentrifuge tube, using a Tissue Lyser II (Qiagen) at $30 \mathrm{~Hz}$ for $2 \mathrm{~min}$. Cell debris was pelleted by centrifugation at $10,000 \times \mathrm{g}$ for $10 \mathrm{~min}$ at $4{ }^{\circ} \mathrm{C}$, and the clarified lysate was sequentially filtered through a $0.45 \mu \mathrm{m}$ filter and then a $0.2 \mu \mathrm{m}$ filter to remove small debris and microbes. To characterize this virus preparation, RNA was isolated from $100 \mu \mathrm{L}$ using TRIzol ${ }^{\circledR}$ reagent (as described below), and cDNA template was used for pathogen-specific PCR and qPCR. PCR confirmed the presence of SBV and the absence of other common honey bee viruses, including ABPV, BQCV, CBPV, DWV, IAPV, KBV, and LSVs (Supplemental Figure S11). Quantitative PCR was used to determine the relative abundance of SBV, using SBV RNA copy number as a proxy for virus abundance, while recognizing that in this crude virus preparation, RNA copies may represent both RNA genomes and transcripts. The SBV inoculum contained 5900 copies/ng RNA. Each well of a 48-well plate was inoculated with $2.5 \times 10^{6}$ SBV RNA copies.

\subsubsection{Deformed Wing Virus}

DWV inoculum was prepared according to standard methods [176]. In brief, whiteeyed pupae were carefully removed from the brood comb and collected into a petri dish lined with filter paper dampened with sterile water. Microcapillary glass needles for injections were made by pulling borosilicate glass capillary tubes (100 $\mathrm{mm}$ long, $1 \mathrm{~mL}$ capacity, Kimble-Chase) with a coil temperature of $61^{\circ} \mathrm{C}$ on the PC-10 Dual-Stage Glass Micropipette Puller (Narishige). Pupae were injected with DWV $\left(3.41 \times 10^{7}\right.$ DWV RNA copies in $2 \mu \mathrm{L}$ ) between the 2 nd and 3rd integuments of the abdomen using the borosilicate glass needle and a Harbo syringe (Honey bee Insemination Service). Pupae were incubated at $30^{\circ} \mathrm{C}$ in a humid incubator over the course of infection and examined daily to ensure they were alive. Live pupae were harvested at 10 days post-injection, and individual pupae were homogenized in $1 \mathrm{~mL}$ PBS ( $\mathrm{pH} 7.4)$ using a sterile steel ball $(5 \mathrm{~mm})$ and Tissue Lyser II (Qiagen) at $30 \mathrm{~Hz}$ for $2 \mathrm{~min}$. Cell debris was pelleted by centrifugation at 10,000 $\times g$ for $10 \mathrm{~min}$ at $4{ }^{\circ} \mathrm{C}$. To characterize this virus preparation, RNA was isolated from $100 \mu \mathrm{L}$ using TRIzol ${ }^{\circledR}$ reagent (Invitrogen) (as described below), and cDNA template was used for pathogen-specific PCR and qPCR. PCR confirmed the presence of DWV and the absence of other common honey bee viruses, including ABPV, BQCV, CBPV, IAPV, KBV, LSVs, and SBV (Supplemental Figure S12). Quantitative PCR was used to determine the relative abundance of DWV, using virus RNA copy number as a proxy for virus abundance, while 
recognizing that in this crude virus preparation, RNA copies may represent both RNA genomes and transcripts. The DWV inoculum contained $5.48 \times 10^{7} \mathrm{DWV}$ RNA copies $/ \mu \mathrm{L}$. For DWV infection studies, approximately $10^{6}$ pupal cells in $300 \mu \mathrm{L}$ (per well in a 48 -well plate) were inoculated with $4.3 \times 10^{6}$ DWV RNA copies.

\subsubsection{Flock House Virus}

FHV was propagated in Drosophila melanogaster Schneider 2 (S2) cells (Invitrogen), an immortalized cell line originally derived from $D$. melanogaster embryos. S2 cells were grown in Schneider's Drosophila medium supplemented with $10 \%$ heat-inactivated fetal bovine serum (Life Technologies) and 1\% penicillin-streptomycin. A sterile T75 flask was seeded with $4 \times 10^{7} \mathrm{~S} 2$ cells $/ \mathrm{mL}$ and infected with FHV at a multiplicity of infection of $1 \mathrm{pfu} / \mathrm{cell}$, as provided by Dr. Anette Schneemann (The Scripps Research Institute, La Jolla, CA, USA). The virus stock was quantified via plaque assay by the Schneemann lab using previously described protocols [177]. The S2 cells infected using this aliquot were incubated at $28{ }^{\circ} \mathrm{C}$ for $48 \mathrm{~h}$, lysed by addition of $10 \%(v / v)$ Nonidet P-40, and incubated on ice for 10 min with periodic swirling [178]. Cell debris was pelleted at $13,800 \times g$ for $10 \mathrm{~min}$ at $4{ }^{\circ} \mathrm{C}$, and the clarified supernatant was transferred to a fresh tube. Using an ultracentrifuge (Beckman Coulter), virus was pelleted through $1 \mathrm{~mL}$ volume of $30 \%$ (wt $/ w t$ ) sucrose in $50 \mathrm{mM}$ HEPES $(\mathrm{pH} 7)$ at $40,000 \mathrm{rpm}$ for $2.5 \mathrm{~h}$ at $11^{\circ} \mathrm{C}$ in a SW41 Ti swinging-bucket rotor. The resulting pellets were resuspended in $0.5 \mathrm{~mL}$ buffer (HEPES $50 \mathrm{mM}, \mathrm{pH}$ ), and any remaining insoluble material was removed by centrifugation at 10,000 rpm for $10 \mathrm{~min}$. The clarified supernatant was layered on a continuous sucrose gradient $(40 \%, 35 \%, 30 \%, 25 \%, 20 \%, 15 \%$, and $10 \%(w t / w t))$ and centrifuged at $40,000 \mathrm{rpm}$ for $1.5 \mathrm{~h}$ at $11{ }^{\circ} \mathrm{C}$ to sediment the virus between $25-35 \%$ sucrose gradients. RNA was isolated from $100 \mu \mathrm{L}$ virus preparations (as described below), and FHV abundance was quantified by qPCR, with the copy number based on a standard curve. For the infection experiments described herein, hemocytes were infected with $1 \times 10^{6}$ FHV RNA copies, and pupal cells were infected with $2 \times 10^{8} \mathrm{FHV}$ RNA copies. FHV infection experiments were monitored over a time course from $0 \mathrm{~h}$ to $96 \mathrm{~h}$ post-infection.

\subsection{Transfer of Virus Infection from Infected to Naïve Primary Honey Bee Pupal Cells}

Small amounts of virus-infected cell culture, including cells and culture supernatant, from initial infections were transferred to naïve pupal cells, seeded in 48-well plates as described above. Primary purple-eyed honey bee pupal cells were seeded at approximately $10^{6}$ cells per $300 \mu \mathrm{L}$ media and incubated at room temperature overnight before infection. Each well was infected with $10 \mu \mathrm{L}$ of mock- or virus-infected pupal cell culture. The resulting infected cells were incubated at room temperature for $0 \mathrm{~h}, 48 \mathrm{~h}$, and $72 \mathrm{~h}$ post-infection.

\subsection{RNA Isolation}

RNA was isolated from cultured adherent hemocytes or non-adherent pupal cells / cell culture media at indicated time points using TRIzol ${ }^{\circledR}$ reagent (Invitrogen) according to manufacturer's instructions. In brief, cell culture medium from each well $(300 \mu \mathrm{L})$ was collected into a microcentrifuge tube. Then, $300 \mu \mathrm{L}$ of TRIzol ${ }^{\circledR}$ reagent (Invitrogen) was added to each well, incubated for $1 \mathrm{~min}$, and then combined with the corresponding cell culture media sample. Samples were stored at $-80^{\circ} \mathrm{C}$ until RNA extraction. To complete RNA isolation, an additional $450 \mu \mathrm{L}$ of TRIzol was added to each sample, which was vortexed and incubated at room temperature for $5 \mathrm{~min}$. Then, $160 \mu \mathrm{L}$ of chloroform was added, and samples were shaken by hand (15 s) and incubated at room temperature ( $2 \mathrm{~min})$. Samples were centrifuged at $12,000 \times g$ for $15 \mathrm{~min}$, and the aqueous phase was transferred to a clean microcentrifuge tube. An equal volume of isopropanol $(\sim 550 \mu \mathrm{L})$ and $20 \mu \mathrm{g}$ of glycogen (Thermo Scientific) were added to the aqueous phase, which was then mixed by inverting. RNA was precipitated after overnight incubation $(\sim 18 \mathrm{~h})$ at $-20{ }^{\circ} \mathrm{C}$ by centrifugation at $4{ }^{\circ} \mathrm{C}$ for $15 \mathrm{~min}$ at $14,000 \times g$. Supernatants were carefully removed by pipetting, 
and each pellet was washed twice with $75 \%$ ethanol. Final pellets were air-dried at room temperature until visually dry ( $20 \mathrm{~min})$. The pellet was suspended in $30 \mu \mathrm{L}$ nuclease-free water; then, $3 \mu \mathrm{L} 3 \mathrm{M}$ sodium acetate ( $\mathrm{pH} 5.5)$ and $120 \mu \mathrm{L}$ ethanol were added, and RNA was precipitated overnight at $-20{ }^{\circ} \mathrm{C}$. Next, samples were centrifuged at $14,000 \times g$ for $15 \mathrm{~min}$, and supernatants were carefully removed by pipetting. Each pellet was washed twice with $75 \%$ ethanol. Finally, RNA pellets were air-dried at room temperature until visually dry ( $\sim 20 \mathrm{~min})$ and then dissolved in $20 \mu \mathrm{L}$ nuclease-free water. RNA concentration was measured using a NanoDrop 2000 spectrophotometer (Thermo Fisher).

To extract RNA from larval carcasses, $300 \mu \mathrm{L}$ of deionized $\mathrm{H}_{2} \mathrm{O}$ was added to the exsanguinated carcass. The carcass was homogenized with a sterile steel BB using a TissueLyzer (Qiagen) at $30 \mathrm{~Hz}$ for $2 \mathrm{~min}$. Then, $800 \mu \mathrm{L}$ TRIzol ${ }^{\circledR}$ reagent (Invitrogen) was added to the lysate and vortexed and incubated at room temperature for $5 \mathrm{~min} ; 200 \mu \mathrm{L}$ of chloroform was then added. The tubes were shaken by hand for $15 \mathrm{~s}$ and incubated at room temperature for $2 \mathrm{~min}$. The samples were then centrifuged for $15 \mathrm{~min}$ at $4{ }^{\circ} \mathrm{C}$ at $12,000 \times g$. The aqueous phase was transferred to a clean microcentrifuge tube (approximately $800 \mu \mathrm{L}$ ), one volume of isopropanol was added, and tubes were mixed by inverting. Samples were incubated at $-20^{\circ} \mathrm{C}$ for one hour and then centrifuged for $10 \mathrm{~min}$ at $4{ }^{\circ} \mathrm{C}$ at $12,000 \times g$. The supernatant was decanted, and the pellet was washed by adding $500 \mu \mathrm{L} 75 \%$ ethanol and centrifuging for $5 \mathrm{~min}(7500 \times \mathrm{g})$ at $4{ }^{\circ} \mathrm{C}$. The supernatant was decanted, and pellets were air-dried at room temperature. Pellets were suspended in $100 \mu \mathrm{L}$ of $\mathrm{dH}_{2} \mathrm{O}$.

\subsection{Reverse Transcription/cDNA Synthesis}

Reverse transcription (RT) reactions to produce complementary DNA (cDNA) were performed by incubating 100-250 ng total RNA for cultured cell experiments, 200 units M-MLV reverse-transcriptase (Promega), and $500 \mathrm{ng}$ random hexamer primers (IDT) for $2 \mathrm{~h}$ at $37^{\circ} \mathrm{C}$, according to the manufacturer's instructions. For larvae/hemocyte assays, 2000 and 1000 ng total RNA, respectively, were used for RT reactions.

\subsection{Negative Strand-Specific RT-PCR}

Virus-treated samples (with SBV, DWV, or FHV) were analyzed for the presence of the negative-strand RNA of the viral genome (i.e., the replicative intermediate form) using strand-specific PCR $[88,179,180]$. Reverse transcription/cDNA synthesis reactions were performed with M-MLV (Promega) according to the manufacturer's instructions using negative strand-specific primers tagged with an additional $21 \mathrm{nt}$ of sequence at their $5^{\prime}$ end (Supplemental Table S1). The tag sequence (5'GGCCGTCATGGTGGCGAATAA3') shares no homology with the viruses used in this study nor with the honey bee genome. Reactions were carried out by incubating 100-250 ng RNA and primers (10 pmol specific or $500 \mathrm{ng}$ hexamers) with 200 units M-MLV reverse-transcriptase (Promega) according to the manufacturer's instructions. Reverse transcription reactions were incubated for 2 at $37^{\circ} \mathrm{C}$. Unincorporated primers present in the RT reactions were digested with 2 units exonuclease I (Life Technologies) per reaction at $37^{\circ} \mathrm{C}$ for $30 \mathrm{~min}$, followed by heat inactivation at $85^{\circ} \mathrm{C}$ for $5 \mathrm{~min}$. To detect negative-strand-derived cDNA products, $5 \mu \mathrm{L}$ of cDNA template in $12.5 \mu \mathrm{L}$ aqueous buffer containing $10 \mathrm{pmol}$ of each of a tag-specific forward primer (TAGS) and virus-specific reverse primer (Table S1) was amplified with $0.5 \mu \mathrm{L}(5 \mathrm{U} / \mu \mathrm{L}$ ) ChoiceTaq polymerase (Thomas Scientific) using the following cycling conditions: $95^{\circ} \mathrm{C}$ for $5 \mathrm{~min}$; $95{ }^{\circ} \mathrm{C}$ for $30 \mathrm{~s}, 55^{\circ} \mathrm{C}$ for $30 \mathrm{~s}, 72{ }^{\circ} \mathrm{C}$ for $45 \mathrm{~s}$, 35 cycles; final elongation $72{ }^{\circ} \mathrm{C}$ for $5 \mathrm{~min}$, hold at $4{ }^{\circ} \mathrm{C}$. Negative control PCR reactions were performed using template generated from RNA-containing RT reactions that were incubated in the absence of RT enzyme or using cDNA template that was generated using random-hexamer primers and only including the reverse primer in the PCR. Positive controls included PCR using virus-specific qPCR primers (Supplemental Table S1). Viral and other long single-stranded RNA molecules often exhibit secondary structures, which serve to prime reverse transcription reactions in the absence of exogenous primers (i.e., self-priming). To test for self-priming, RT reactions 
were carried out in the absence of primers, followed by PCR with virus-specific qPCR primers (See Supplemental Table S1 for full list of controls).

\subsection{Polymerase Chain Reaction (PCR)}

PCR was performed according to standard methods [33,63,64,97]. In brief, $2 \mu \mathrm{L}$ cDNA template in $12.5 \mu \mathrm{L}$ aqueous buffer containing $10 \mathrm{pmol}$ of each forward and reverse primer (Table S1) was amplified with $0.5 \mu \mathrm{L}(5 \mathrm{U} / \mu \mathrm{L})$ ChoiceTaq polymerase (Thomas Scientific) according to the manufacturer's instructions using the following cycling conditions: $95^{\circ} \mathrm{C}$ for $5 \mathrm{~min} ; 95^{\circ} \mathrm{C}$ for $30 \mathrm{~s}, 55^{\circ} \mathrm{C}$ for $30 \mathrm{~s}, 72{ }^{\circ} \mathrm{C}$ for $45 \mathrm{~s}, 35$ cycles; final elongation $72{ }^{\circ} \mathrm{C}$ for $5 \mathrm{~min}$, hold at $4{ }^{\circ} \mathrm{C}$. PCR products were visualized by $1.5 \%$ agarose gel electrophoresis and stained with SYBRsafe (Invitrogen). Positive and negative control reactions were included for all analyses and exhibited the expected results. Select products were purified with the Qiaquick PCR Purification Kit (Qiagen), quantified using a NanoDrop spectrophotometer (Fisher), and Sanger sequenced.

\subsection{Quantitative PCR}

Quantitative PCR (qPCR) was used to quantify the viral RNA (i.e., genome and transcript) abundance in the samples and assess the relative abundances of honey bee encoded transcripts (i.e., a housekeeping gene, $r p l 8$ ), and three immune genes (i.e., ago2, dcr-like, and bap1/mf116383) using the primer sets listed in Supplemental Table S1. All qPCR reactions were performed in triplicate using $2 \mu \mathrm{L}$ of cDNA template and a no-template negative control was run in triplicate for each qPCR reaction. Each $20 \mu \mathrm{L}$ reaction contained $1 \times$ Denville ChoiceTaq Mastermix, $0.4 \mu \mathrm{M}$ each forward and reverse primer, $1 \times \mathrm{SYBR}$ Green (Life Technologies), and $3 \mathrm{mM} \mathrm{MgCl}_{2}$. Reactions were carried out in 96-well plates using a CFX Connect Real-Time instrument using Maestro software (Bio-Rad) with the following thermo-profile: initial denaturation at $95^{\circ} \mathrm{C}$ for one minute; followed by 40 cycles of $95^{\circ} \mathrm{C}$ for $10 \mathrm{~s}, 58^{\circ} \mathrm{C}$ for $20 \mathrm{~s}$, and $72{ }^{\circ} \mathrm{C}$ for $15 \mathrm{~s}$, with a final melt curve analysis at $65{ }^{\circ} \mathrm{C}$ for $5 \mathrm{~s}$ to $95^{\circ} \mathrm{C}$. Positive and negative control reactions were included for all qPCR analyses and exhibited the expected results. Viral RNA copies were estimated using a plasmid DNA standard for SBV, DWV, and FHV, with a detection range of $10^{3}$ to $10^{9}$ to create a linear standard curve used for copy number interpolation. The linear equation for the plasmid standard for FHV was $C t=-3.240 x+40.138\left(R^{2}=0.980\right.$, efficiency $\left.=103 \%\right)$, determined by a previously described method [181]. Similarly, the linear equation for DWV was $C t=-3.5627 x+39.091\left(R^{2}=0.9973\right.$, efficiency $\left.=90.5 \%\right)$. The linear equation for the SBV standard curve was $C t=-3.39 x+37.42\left(R^{2}=0.994\right.$, efficiency $\left.=97.2 \%\right)$. The relative expression of host genes was determined by a ranked $\Delta \Delta \mathrm{Ct}$ method in which the $\Delta \mathrm{Ct}$ was calculated by subtracting the rpls $\mathrm{Ct}$ value from the $\mathrm{Ct}$ of the gene of interest. Then, the within-group $\Delta \mathrm{Ct}$ values were ranked from highest to lowest, and the relevant corresponding control $\Delta \mathrm{Ct}$ value was subtracted from the treatment group $\Delta \mathrm{Ct}$ to obtain the $\Delta \Delta \mathrm{Ct}$. The fold-change in cDNA abundance was calculated by the equation $2^{-\Delta \Delta \mathrm{Ct}}$. See Supplemental Tables S2-S12 for qPCR data presented in the figures.

\subsection{Microscopy}

To prepare hemocytes for imaging, they were isolated as above and seeded into \#1.5 German cover glass chamber slides (Thermo Fisher Scientific) in WH2 media. Live-cell and fixed-cell images were taken on a Nikon Ti-Eclipse (Nikon Instruments) inverted microscope equipped with a SpectraX LED (Lumencor) excitation module and fast-switching emission filter wheels (Prior Scientific). Brightfield images were captured using a Plan Fluor 20 phase contrast $(\mathrm{Ph})$ objective and an iXon 896 EM-CCD (Andor Technology Ltd.) camera using NIS Elements software. To visualize cells with an intact nucleus, the cell culture media was removed, and the cells were washed with PBS and then incubated in $4 \%$ paraformaldehyde in PBS for $10 \mathrm{~min}$ at room temperature. The paraformaldehyde containing PBS was removed, and cells were washed two times with PBS. Hoechst stain (Hoechst 33258, Invitrogen) prepared to $30 \mathrm{mg} / \mathrm{mL}$ in PBS was further diluted 1:5000 in 
PBS to create a working solution, which was then overlaid on the cells. Then, fluorescent images were captured using paired excitation/emission filters and dichroic mirrors for DAPI (Chroma Technology Corp).

\subsection{Statistical Analysis}

All data were analyzed using R v4.0.2 in RStudio V1.3.1073. Unless otherwise stated, comparisons for virus abundance were evaluated using the DunnettTest function in the DescTools R stats package to perform the post hoc pairwise multiple comparisons to a control [182]. Relative gene expression differences were evaluated using a one-sided Wilcoxon [183]. For each analysis, comparisons were considered significant if $p<0.05$.

\section{Results and Discussion}

\subsection{Sacbrood Virus (SBV) Replicates in Primary Honey Bee Hemocytes}

To determine whether sacbrood virus (SBV) infects hemocytes, the primary immune cell in honey bees, approximately $1 \times 10^{5}$ larval (L4-L5) hemocytes were seeded into wells of a 48-well tissue culture plate with relatively few contaminating adipocytes and treated with either phosphate buffered saline (PBS) or SBV (i.e., bee larval lysate containing $2.5 \times 10^{6}$ SBV RNA copies) (Supplemental Figure S1). Cells were harvested at distinct time points post-infection (i.e., from 0 hours post-infection (hpi) to $96 \mathrm{hpi}$ ) and virus abundance, using RNA copy number as a proxy, was determined by qPCR. In one experimental replicate, the primary honey bee hemocyte culture had a pre-existing SBV infection, which exhibited a $501 \times$ increase in SBV by 96 h post-treatment $(p=0.042)$ (Figure $1 \mathrm{~A})$. This result indicates that hemocytes are a natural site of SBV infection and that SBV virus infections can persist in cells grown in culture. The addition of SBV increased the infection level by $13 \times$ over the initial levels by $24 \mathrm{hpi}(p<0.001)$, and it rose to $69.2 \times$ by $48 \mathrm{hpi}$ $(p<0.001)$, to $147.9 \times$ by 72 hpi $(p<0.0001)$, and peaked at $354.8 \times$ at $96 \mathrm{hpi}(p<0.0001)$. In a second biological replicate of this experiment, confounding SBV infection was not detected (Figure 1B). In inoculated hemocytes, there was a $24 \times$ increase from $0 \mathrm{hpi}$ to 24 hpi $(p=0.0001)$, and by 48 hpi SBV had increased $182 \times(p<0.0001)$ and reached peak infection. There was a decrease in SBV relative to $48 \mathrm{hpi}$ at $72 \mathrm{hpi}$ (i.e., $49 \times$ greater virus levels than at $0 \mathrm{hpi}, p<0.0001$ ), with a subsequent rise at $96 \mathrm{hpi}$ (i.e., $132 \times$ increase over $0 \mathrm{hpi}, p<0.0001)$. Although it is unclear why there was a reduction in viral abundance at $72 \mathrm{hpi}$, it could have been due to a decrease in the number of permissive hemocytes in the culture; by $96 \mathrm{hpi}$, cell division and/or differentiation may have occurred and resulted in additional susceptible host cells.

To further validate that the increase in SBV over the infection time course was due to active virus replication in honey bee hemocytes, we carried out strand-specific RT-PCR. The SBV genome is positive-sense single-stranded RNA (+ssRNA). During virus replication, a negative strand template is produced $[88,179,180,184]$. The negative strand of SBV was not detected in the inoculum (i.e., at $0 \mathrm{hpi}$ ), but was detected at all other time points (Figure 1C). Together these data indicate that not only does SBV actively replicate in hemocytes, but hemocytes also serve as a natural site of virus infection. Furthermore, virus testing of honey bee larvae (i.e., corresponding carcass and hemocyte samples) indicate that hemocytes are natural sites of infection for black queen cell virus (BQCV) (Supplemental Table S24). While, in general, hemocytes had low incidence of infection, isolated larval hemocytes were positive for BQCV in $9.1 \%$ of cases where the larval carcass was also BQCV-positive (Supplemental Table S24). Together, these data suggest hemocytes might be a site of infection for multiple viruses. These results are in line with reports of virus infections in other invertebrates, including persistent infection of hemocytes by hepatitis A virus (HAV) and murine norovirus (MNV) in oysters (Crassostrea virginica) [185]. In addition, white spot syndrome virus (WSSV) infects subpopulations of shrimp hemocytes [186]. Results from honey bees, oysters, and shrimp differ from the observation that hemocytes of Sindbis-virus-infected Drosophila melanogaster remain uninfected [170]. As described above, hemocytes consist of several subpopulations. Future studies aimed at identifying 
the hemocyte subpopulations that are permissive to specific viruses will provide insight into the role of these important immune cells in virus dissemination and antiviral defense. Understanding how viruses interact with hemocytes and how they might frustrate the cellular immune function may aid in the long-term goal of developing therapeutics and technologies that mitigate the negative impacts of viruses on bees.

A

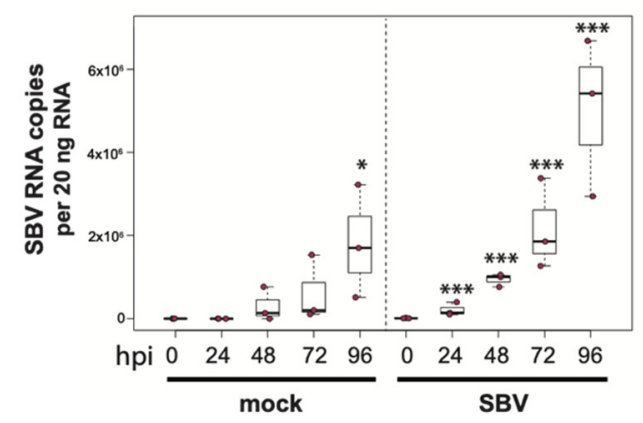

C

\begin{tabular}{|c|c|c|c|c|c|c|c|c|c|c|c|c|c|c|}
\hline \multirow[b]{2}{*}{$\mathrm{L}$} & \multicolumn{5}{|c|}{ hpi } & \multicolumn{9}{|c|}{ lane } \\
\hline & 0 & 24 & 48 & 72 & 96 & 1 & 2 & 3 & 4 & 5 & 6 & 7 & 8 & 9 \\
\hline 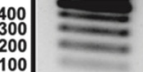 & * & - & 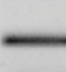 & $=$ & - & - & & . & & & & - & & \\
\hline
\end{tabular}

Figure 1. Sacbrood virus (SBV) naturally infects hemocytes and replicates in primary honey bee hemocyte cell cultures. SBV abundance was assessed in mock- or SBV-treated larval hemocytes by qPCR over a time course (i.e., 0 hpi, 24 hpi, 48 hpi, $72 \mathrm{hpi}$, and $96 \mathrm{hpi}$ ). (A) Cells isolated from asymptomatic larvae and treated with PBS (pH 7.4) had a 501× increase in mean SBV abundance by 96 hpi relative to 0 hpi $(p=0.042)$, indicating that the hemocytes in this experimental replicate had a pre-existing SBV infection and that hemocytes are a natural site of infection for SBV. The addition of filtered larval lysate containing $2.5 \times 10^{6}$ SBV RNA copies resulted in a $13 \times$ increase by 24 hpi relative to 0 hpi $(p<0.001)$ and a peak fold increase of $355 \times$ by 96 hpi $(p<0.0001)$. (B) In a second replicate of the experiment, mock-infected cells remained uninfected over the course of the experiment. The addition of filtered larval lysate containing $2.5 \times 10^{6}$ SBV RNA copies resulted in a peak fold increase of $182 \times(p<0.0001)$ at $48 \mathrm{hpi}$, with a decrease at $72 \mathrm{hpi}(49 \times$ relative to $0 \mathrm{hpi}, p<0.0001)$ and a subsequent rise again at $96 \mathrm{hpi}(132 \times$ relative to $0 \mathrm{hpi}, p<0.0001)$. Raw data are included in Supplemental Table S2. All differences in means relative to 0 hpi were assessed by a Dunnett's test. Significance levels: ${ }^{*} p<0.05 ;{ }^{* *} p<0.0005$. (C) To confirm that SBV was productive in infecting larval hemocytes, the presence of the negative strand (a replicative intermediate) was assessed by negative-strand-specific reverse transcription (RT) followed by PCR. Negative strand was detected at all time points after $0 \mathrm{hpi}$. Additional control reactions were performed using pooled RNA from time points 24-96 hpi (Lanes labeled 1-9). Specifically, RNA isolated from SBV containing cell lysate was reverse transcribed with the primer listed below, treated with Exonuclease I to remove excess primer, and amplified using the PCR primers listed for each lane. (L) Molecular weight ladder. (0, 24, 48, 96 hpi)—RT with random hexamers, PCR with SBV-221-240-For and SBV-478-497-Rev. (1) Negative control: No RT in the presence of (SBV-TAGS-F), PCR with TAGS and SBV-478-497-Rev. (2) Negative control: RT in the presence of (SBV-TAGS-F), PCR with only the SBV-478-497-Rev primer. (3) Negative control: RT with random hexamer primer, PCR with TAGS and SBV-478-497-Rev. (4) Negative control: No RT enzyme in the presence of random hexamers, PCR with SBV-221-240-For and SBV-478-497-Rev. (5) Positive control: RT with random hexamers, PCR with SBV-221-240-For and SBV-478-497-Rev. (6) Negative control: RT with random hexamers, PCR with only SBV-478-497-Rev primer. (7) Self-priming: RT without a primer, PCR with SBV-221-240-For and SBV-478-497-Rev. (8) Negative control: No template, no RT, PCR with TAGS and SBV-478-497-Rev. (9) Negative control: No template, no RT, PCR with SBV-221-240-For and SBV-478-497-Rev. Additional details provided in Supplemental Table S25. When reverse transcription was performed without primer, SBV cDNA was detectable (lane 7), indicating that the secondary structure in the RNA genome may serve as a primer for cDNA synthesis.

To our knowledge, this is the first quantitative evidence that SBV productively infects honey bee hemocytes. A previous study used transmission electron microscopy to visualize 
SBV virions within larval and adult hemocytes [168]. While those images indicated that SBV may replicate in hemocytes, they could have also been explained by phagocytosis of virions [168]. The observation that honey bee hemocytes are naturally infected by SBV has important implications for viral pathogenesis. While we did not observe any cytopathic effects (CPEs), it is possible the cells would have shown CPEs if the experiments were carried out for a longer time period. Additionally, the immune function of hemocytes may be dysregulated by viral infection, since viruses subvert cellular processes and disrupt cellular homeostasis $[187,188]$. For example, DWV suppresses larval melanization in response to wounding, suggesting an interaction between DWV and hemocytes [96]. This is further supported by gene expression studies of DWV-infected larvae, which exhibited reduced expression of $A m e l \backslash 102$, a gene involved in melanization and encapsulation [96].

In addition to hosting viral infection, honey bee hemocytes are likely instrumental in antiviral immune responses, as they are in Drosophila melanogaster. Direct evidence for an antiviral role for hemocytes in fruit flies includes the results of in vivo experiments in which hemocytes were either saturated via injection of latex beads or genetically depleted [189]. Flies with reduced hemocyte function that were infected with either Cricket paralysis virus (CrPV), FHV, or vesicular stomatitis virus (VSV) had increased viral abundance and higher mortality than flies with phagocytic hemocytes. In contrast, reduced hemocyte function had no impact on Drosophila C virus (DCV), Sindbis virus (SINV), and Invertebrate iridescent virus 6 (IIV6) infections in flies [189]. These results also indicated that the relative importance of hemocytes in host antiviral defense will vary for specific host-virus pairs and may also depend on additional factors (e.g., co-infection, nutritional status, age). Hemocytes are required for systemic adaptive RNAi response in flies, which limits virus infection $[170,171]$. This finding provides strong support for an antiviral role of hemocytes against some viruses in fruit flies, which suggests that hemocytes likely serve an antiviral role in insects in general.

While the function of hemocytes in honey bee antiviral response requires further investigation, there is limited indirect evidence of their antiviral role. Specifically, genes involved in migration, phagocytosis, and expression immunoglobulin domain encoding, were expressed at greater levels in honey bees infected with a model virus, SINV, relative to mock-infected bees [107]. Additionally, IAPV infection resulted in increased expression of genes involved in cell projection, cellular organization, autophagic cell death, microtubulebased movement, and phagocytosis [101,190]. Our observation that viruses replicate in cultured hemocytes will facilitate future studies aimed at elucidating their role in antiviral defense, including further investigation of the genes and processes highlighted by transcriptional level studies.

\subsection{Sacbrood Virus (SBV) Replicates in Primary Honey Bee Pupal Cell Cultures}

To determine whether a mixed cell culture derived from purple-eyed pupae supported SBV infection, approximately $1 \times 10^{6}$ cells were treated with either PBS or SBV (i.e., bee larval lysate containing $2.5 \times 10^{6} \mathrm{SBV}$ RNA copies). Cells were harvested at distinct time points post-infection, and virus abundance was assessed by qPCR. Three independent experiments were performed (Supplemental Figure S2). In replicate one, SBV abundance was $7.8 \times$ higher by $48 \mathrm{hpi}$ than the levels after $0 \mathrm{hpi}(p<0.0001)$. SBV abundance remained high at 72 hpi $(12 \times, p<0.0001)$ and 96 hpi $(11.4 \times, p<0.0001)$ (Supplemental Figure S2A). Likewise, in the second experimental replicate, SBV abundance was higher by $48 \mathrm{hpi}$ $(59 \times, p<0.0001)$, remained high at $72 \mathrm{hpi}(126 \times, p<0.001)$, and peaked at $96 \mathrm{hpi}(1047 \times$, $p<0.0001$ ) (Figure 2A and Figure S2B). While SBV levels at 24 hpi were close to the levels of the $0 \mathrm{hpi}$ time points in the first two biological replicates, they were significantly lower in replicate three (i.e., $0.017 \times, p<0.0001$ ). Like the other two replicates, SBV levels increased by $48 \mathrm{hpi}(2.2 \times, p=0.0012)$, remained high at $72 \mathrm{hpi}(14 \times, p=0.00013)$, and peaked at $96 \mathrm{hpi}$ $(72 \times, p<0.0001)$ (Supplemental Figure S2C). The overall increase in SBV levels for replicate three was $1,817 \times$ (i.e., from 24 hpi to 96 hpi $(p<0.0001)$ ), which was similar to replicate two, which had an overall $1047 \times$ increase, whereas the replication and relative increase 
in abundance for replicate one was lower (i.e., only $72 \times$ ) (Supplemental Figure S2A). To further verify that SBV productively infected cultured honey bee pupal cells, we used strand-specific RT-PCR to assay for the negative strand (i.e., replicative intermediate form of SBV). The SBV-negative strand was detected at three time points post-infection, which corresponded to peak virus abundances (i.e., 48, 72, and 96 hpi) (Figure 2B). Together, these data demonstrate that primary honey bee pupal cell cultures are permissive to SBV infection. Furthermore, since the fold increase of SBV in honey bee pupal cells was greater than in hemocytes, we hypothesize that cell types present in pupal cultures, including endothelial cells and fibroblasts, may be more suitable hosts for SBV compared to immune cells.

A

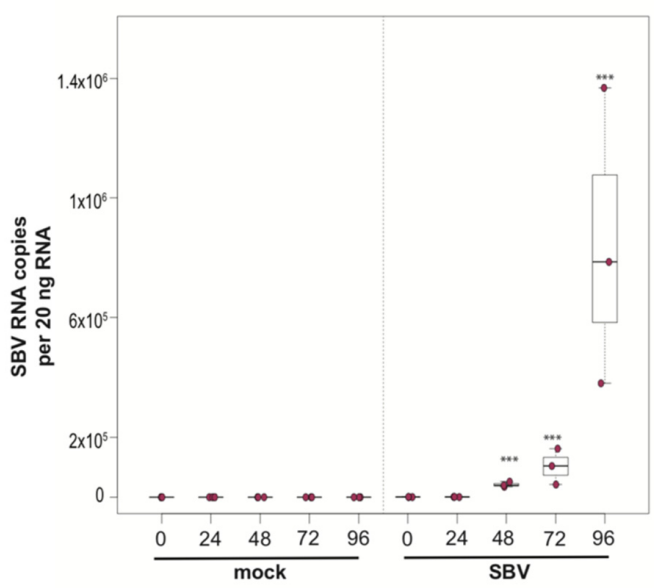

B

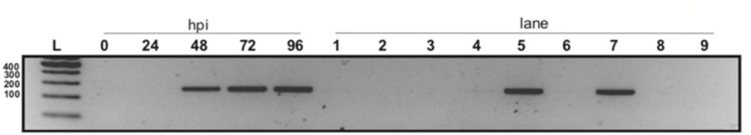

Figure 2. Sacbrood virus (SBV) replicates in primary honey bee pupal cell cultures. (A) SBV abundance was assessed in mock- or SBV-treated pupal cells by qPCR over a time course (i.e., 0 hpi, 24 hpi, $48 \mathrm{hpi}, 72 \mathrm{hpi}$, and $96 \mathrm{hpi}$. A representative replicate of SBV-infection in pupal cells is plotted. The addition of larval lysate to pupal cells resulted in a $59 \times$ fold increase relative to 0 hpi by 48 hpi $(p<0.0001)$, with subsequent increases at $72 \mathrm{hpi}(126 \times, p<0.0001)$ and $96 \mathrm{hpi}(1047 \times, p<0.0001)$. Raw data are included in Supplemental Table S3. See Supplemental Figure S2 for additional replicates. All differences in means relative to 0 hpi were assessed by a Dunnett's test. Significance levels: *** $p<0.0005$. (B) To confirm that SBV was productive in infecting larval hemocytes, the presence of the negative strand (a replicative intermediate) was assessed by negative strand-specific reverse transcription (RT) followed by PCR. Negative strand was detected at all time points after 24 hpi. Additional control reactions were performed using pooled RNA from time points 24-96 hpi (Lanes labeled 1-9). Specifically, RNA isolated from SBV containing cell lysate was reverse-transcribed with the primer listed below, treated with Exonuclease I to remove excess primer, and amplified using the PCR primers listed for each lane. (L) Molecular weight ladder. (0, 24, 48, 96 hpi)—RT with random hexamers, PCR with SBV-221-240-For and SBV-478-497-Rev. (1) Negative control: No RT in the presence of (SBV-TAGS-F), PCR with TAGS and SBV-478-497-Rev. (2) Negative control: RT in the presence of (SBV-TAGS-F), PCR with only the SBV-478-497-Rev primer. (3) Negative control: RT with random hexamer primer, PCR with TAGS and SBV-478-497-Rev. (4) Negative control: No RT enzyme in the presence of random hexamers, PCR with SBV-221-240-For and SBV-478-497-Rev. (5) Positive control: RT with random hexamers, PCR with SBV-221-240-For and SBV-478-497-Rev. (6) Negative control: RT with random hexamers, PCR with only SBV-478-497-Rev primer. (7) Self-priming: RT without a primer, PCR with SBV-221-240-For and SBV-478-497-Rev. (8) Negative control: No template, no RT, PCR with TAGS and SBV-478-497-Rev. (9) Negative control: No template, no RT, PCR with SBV-221-240-For and SBV-478-497-Rev. Additional details provided in Supplemental Table S25. 
While the primary concern of SBV infection of honey bee colonies is larval mortality, SBV also reduces adult lifespan. SBV infections in pupae may inhibit the melanization pathway by causing reduced expression of prophenoloxidase activating enzyme (PPAE) and increased expression of a putative serpin protein encoding gene (GB48820) $[59,145]$. Pupae with a suppressed melanization response may be more susceptible to infection after wounding by Varroa destructor mites. It is not known whether SBV-infected pupae can clear infections prior to eclosion, and in turn if SBV-infected pupae can develop into healthy adults. Therefore, tools to study the impact of SBV and the molecular mechanisms of antiviral defense at all life stages are needed and include the SBV-permissive cultured primary cells described herein.

\subsection{Deformed Wing Virus Replicates in Primary Honey Bee Pupal Cells}

To investigate the utility of primary honey bee pupal cells to support DWV infection, approximately $1 \times 10^{6}$ purple-eyed pupal cells were incubated with $4.3 \times 10^{6}$ DWV RNA copies. Cells were harvested at distinct time points post-infection (i.e., from $0 \mathrm{hpi}$ to $96 \mathrm{hpi}$ ), and virus abundance, using RNA copy number as a proxy, was determined by qPCR. Data from two independent experiments demonstrated that DWV abundance increased from 0 hpi to 96 hpi (Supplemental Figure S3). In replicate one, DWV levels remained unchanged for the first $24 \mathrm{~h}$ and were $2.7 \times$ greater at $48 \mathrm{hpi}(p=0.002)$. DWV abundance increased $3.5 \times$ and $4 \times$ at $72 \mathrm{hpi}(p<0.001)$ and $96 \mathrm{hpi}(p<0.001)$, respectively, with peak DWV levels at $96 \mathrm{hpi}$ relative to $0 \mathrm{hpi}$ (Figure 3A). In replicate two, DWV levels remained similar to inoculum levels through $48 \mathrm{hpi}$ but were $3.2 \times$ higher at $72 \mathrm{hpi}(p=0.001)$ and $6.6 \times$ higher at $96 \mathrm{hpi}$, relative to $0 \mathrm{hpi}(p=0.003)$ (Supplemental Figure S3). To verify DWV replication in primary cultures of purple-eyed honey bee pupal cells, negative-strand specific PCR was performed, and the replicative intermediate form (i.e., negative strand) of DWV was detected at 72 hpi (Figure 3B). Together, DWV abundance and negative-strand data confirm that primary cultures of honey bee pupal cells support DWV replication.

The ability to infect primary honey bee cells with DWV opens new avenues for studying a pathogen that has co-evolved with honey bees. Primary cell cultures may also facilitate the propagation of virus stocks that are free of confounding viruses. Experiments in cultured honey bee cells also provide an opportunity to study the mechanistic details of DWV infections and virus-host dynamics in a system that complements experiments carried out in larvae, pupae, and adult honey bees. Recent efforts have focused on exploring the ability of alternative host cell lines to support honey bee virus infections; for example, the Lepidopteran hemocyte-derived cell line (P1) has been shown to support DWV infection [151]. While exploring the ability of alternative cell lines to support honey bee virus infections is an attractive approach, the immune response elicited by these alternative host cells may or may not completely recapitulate the immune response elicited by honey bees. Therefore, the potential to infect primary honey bee cells with naturally infecting honey bee viruses, including DWV, will be a powerful tool to explore the natural host-virus interactions at the cellular level.

\subsection{Flock House Virus Replicates in Primary Honey Bee Hemocytes}

To investigate the ability of honey bee immune cells to support the replication of a model virus, approximately $1 \times 10^{5}$ larval-derived hemocytes maintained in culture were incubated with PBS or FHV $\left(1 \times 10^{6} \mathrm{FHV}\right.$ RNA copies). Cells were harvested at distinct time points post-infection (i.e., from $0 \mathrm{hpi}$ to $96 \mathrm{hpi}$ ), and virus abundance was determined by qPCR. Data from two independent experiments demonstrated that FHV abundance increased from 0 hpi to 72 hpi and decreased from 72 hpi to 96 hpi (Supplemental Figure S4). In replicate one, FHV levels in hemocytes increased $3.7 \times$ by $24 \mathrm{hpi}(p=0.026)$ and $10.7 \times$ by $48 \mathrm{hpi}$, relative to $0 \mathrm{hpi}(p<0.001)$ (Figure $4 \mathrm{~A})$. FHV abundance continued to increase from 48 hpi to $72 \mathrm{hpi}$, which had $37 \times(p<0.001)$ the initial FHV level (i.e., compared to 0 hpi) (Figure 4A). By $96 \mathrm{hpi}$, FHV abundance was less than levels quantified at $72 \mathrm{hpi}(p=0.034)$ but remained significantly higher relative to $0 \mathrm{hpi}(p<0.001)$ (Figure $4 \mathrm{~A})$. One possible 
explanation for reduced FHV abundance at 96 hpi is that, by that time most hemocytes were FHV-infected, there may have been a lack of naïve host cells to support further virus replication. In replicate two of this experiment, FHV abundance was constant at 24 hpi but was $16 \times$ higher at 48 hpi $(p<0.01)$ relative to 0 hpi. At 72 hpi, FHV levels peaked, with $39.8 \times$ higher FHV levels compared to 0 hpi $(p<0.001)$. FHV abundance was reduced at 96 hpi relative to $72 \mathrm{hpi}$ but was still $12.6 \times$ higher that levels at $0 \mathrm{hpi}$ $(p<0.001)$ (Supplemental Figure S4B). To further validate that FHV, which has a +ssRNA genome, productively infected cultured honey bee hemocytes, negative-strand-specific PCR was utilized to detect the replicative intermediate of FHV. Since FHV abundance peaked at $72 \mathrm{hpi}$, this time point was selected to assay for the presence of negative strand, and a negative-strand-specific FHV PCR product was detected (Figure 4B). Together, FHV abundance and negative-strand data demonstrate that FHV productively infects primary honey bee hemocytes maintained in culture.

A

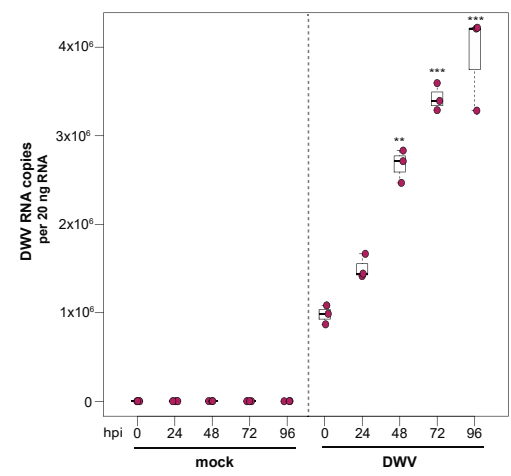

B

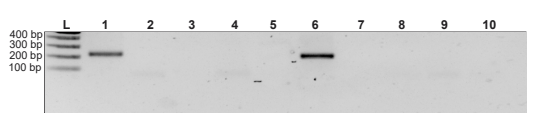

Figure 3. Deformed wing virus (DWV) replicates in primary honey bee pupal cell cultures. DWV abundance was assessed in mock- or DWV-infected pupal cells via qPCR over a time course (i.e., 0 hpi, 24 hpi, 48 hpi, 72 hpi, and 96 hpi). (A) Pupal cells infected with $4.3 \times 10^{6}$ DWV RNA copies had a $2.7 \times(p<0.001)$ and $3.5 \times(p<0.001)$ increase in mean DWV abundance at $48 \mathrm{hpi}$ and $72 \mathrm{hpi}$, respectively, relative to $0 \mathrm{hpi}$. At $96 \mathrm{hpi}$, mean DWV abundance was $4 \times$ higher relative to $0 \mathrm{hpi}$ $(p<0.001)$. Figure 3 includes results from one representative biological replicate. The data for additional replicates are presented in Supplemental Figure S3. All differences in means relative to 0 hpi were assessed by a Dunnett's test. Raw data are included in Supplemental Table S4. Significance levels: ${ }^{* *} p<0.005$; *** $p<0.0005$. (B) To verify DWV replication in purple-eyed pupal cells, negativestrand-specific RT-PCR was performed, and the replicative intermediate form (i.e., negative strand) of DWV was detected at $72 \mathrm{hpi}$. Additional control reactions were performed using pooled RNA from time points 24-96 hpi (Lanes labeled 2-9). Specifically, RNA isolated DWV containing cell lysate was reverse-transcribed with the primer listed below, treated with Exonuclease I to remove excess primer, and amplified using the PCR primers listed for each lane. (L) Molecular weight ladder. (1) 72 hpi RNA template-RT with DWV-TAGS-F, PCR with TAGS and DWV-Rev. (2) Negative control: No RT in the presence of (DWV-TAGS-F), PCR with TAGS and DWV-Rev. (3) Negative control: RT in the presence of (DWV-TAGS-F), PCR with only the DWV-Rev primer. (4) Negative control: RT with random hexamer primer, PCR with TAGS and DWV-Rev. (5) Negative control: No RT enzyme in the presence of random hexamers, PCR with DWV-F and DWV-Rev. (6) Positive control: RT with random hexamers, PCR with DWV-F and DWV-Rev. (7) Negative control: RT with random hexamers, PCR with only DWV-Rev primer. (8) Self-priming: RT without a primer, PCR with DWV-F and DWV-Rev (9) Negative control: No template, no RT, PCR with TAGS and DWV-Rev. (10) Negative control: No template, no RT, PCR with DWV-F and DWV-Rev. Additional details provided in Supplemental Table S25. 
The ability to infect hemocytes with FHV provides an additional tool for investigating virus-honey bee host interactions at the cellular level. This model virus may prove particularly useful in investigating RNAi in the context of viral suppressors, since FHV-B2 protein suppresses RNAi, as confirmed by studies that utilized deletion mutants (i.e., FHV- $\triangle B 2)[128,191]$. To date there have been relatively few studies on putative bee virusencoded VSRs, and the results from IAPV-infected honey bees and bumble bees have mixed results regarding the presence of a VSR; therefore, additional investigation is required $[150,190]$. The proteins produced by other model insect viruses, including cricket paralysis virus and Drosophila C virus, which encode bona fide VSRs, have a conserved amino acid motif (DvExNPGP) downstream of their VSR proteins [192,193]. Sequence analysis indicates that this motif is present in IAPV, KBV, and ABPV, suggesting that these viruses may encode VSRs, although additional studies are needed to identify and validate putative VSRs. Overall, the use of both model viruses and naturally infecting honey bee viruses, including those that do and do not encode RNAi suppressors, will advance our knowledge of the interactions between viruses and the host antiviral RNAi machinery.

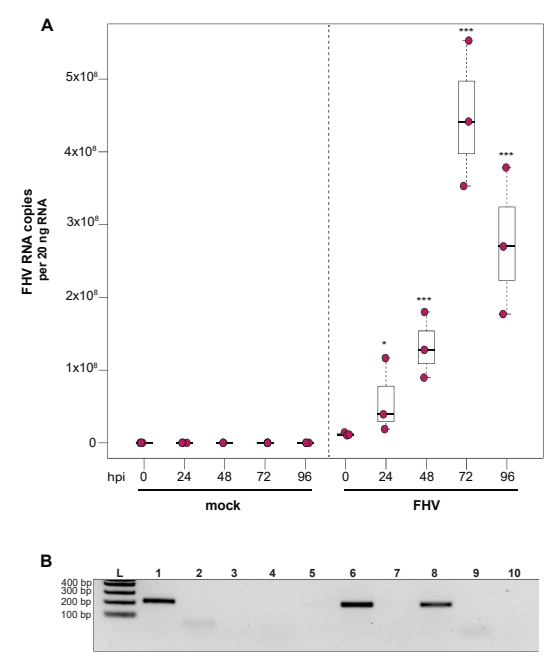

Figure 4. Flock House virus (FHV) replicates in primary honey bee hemocytes. FHV abundance in mock- or FHV-infected $\left(1 \times 10^{6}\right.$ FHV RNA copies) hemocytes was assessed over time (i.e., 0 hpi, $24 \mathrm{hpi}, 48 \mathrm{hpi}, 72 \mathrm{hpi}$, and $96 \mathrm{hpi})$. (A) FHV abundance was higher at $24 \mathrm{hpi}(3.7 \times, p=0.026), 48 \mathrm{hpi}$ $(10.7 \times, p<0.001)$, and $72 \mathrm{hpi}(37 \times, p<0.001)$, relative to 0 hpi. FHV abundance reduced from $72 \mathrm{hpi}$ to $96 \mathrm{hpi}(p=0.034)$ but was significantly higher $(p<0.001)$ relative to 0 hpi. Raw data are included in Supplemental Table S5. Figure 4 includes results from one representative biological replicate. The data for additional replicates are presented in Supplemental Figure S4. All differences in means relative to 0 hpi were assessed by a Dunnett's test. Significance levels: ${ }^{*} p<0.005 ;{ }^{* *} p<0.0005$. (B) FHV-specific negative strand was detected at $72 \mathrm{hpi}$, which confirms that FHV productively infects primary honey bee hemocytes (Lane 1). Additional control reactions were performed using pooled RNA from time points 24-96 hpi (Lanes labeled 2-9). Specifically, RNA-isolated FHV containing cell lysate was reverse-transcribed with the primer listed below, treated with Exonuclease I to remove excess primer, and amplified using the PCR primers listed for each lane. (L) Molecular weight ladder. (1) 72 hpi RNA template-RT with FHV-TAGS-F, PCR with TAGS and FHV-Rev. (2) Negative control: No RT in the presence of (FHV-TAGS-F), PCR with TAGS and FHV-Rev. (3) Negative control: RT in the presence of (FHV-TAGS-F), PCR with only the FHV-Rev primer. (4) Negative control: RT with random hexamer primer, PCR with TAGS and FHV-Rev. (5) Negative control: No RT enzyme in the presence of random hexamers, PCR with FHV-F and FHV-Rev. (6) Positive control: RT with random hexamers, PCR with FHV-F and FHV-Rev. (7) Negative control: RT with random hexamers, PCR with only FHV-Rev primer. (8) Self-priming: RT without a primer, PCR with FHV-F and FHV-Rev. (9) Negative control: No template, no RT, PCR with TAGS and FHV-Rev. (10) Negative control: No template, no RT, PCR with FHV-F and FHV-Rev. Additional details provided in Supplemental Table S25. 


\subsection{Flock House Virus Replicates in Primary Honey Bee Pupal Cells}

To examine the ability of cells derived from purple-eyed honey bee pupae to support infection and replication of FHV, approximately $1 \times 10^{6}$ primary cells in culture were incubated with FHV $\left(2 \times 10^{8}\right.$ FHV RNA copies), and virus abundance was assessed at distinct time points post-infection. FHV abundance increased from 0 hpi to $72 \mathrm{hpi}$ and was reduced or remained constant at $96 \mathrm{hpi}$ in two experimental replicates. In replicate one, FHV levels increased by $1.7 \times$ at $24 \mathrm{hpi}(p=0.024)$ and by $3.4 \times$ at $48 \mathrm{hpi}$, relative to initial levels at 0 hpi $(p<0.001)$. The peak of infection was reached at $72 \mathrm{hpi}$, with $5 \times$ greater FHV levels relative to 0 hpi $(p<0.001)$. FHV abundance in pupal cells did not increase from $72 \mathrm{hpi}$ to $96 \mathrm{hpi}$ but remained $4 \times$ higher than at $0 \mathrm{hpi}(p<0.001)$ (Figure 5A). Similarly, in the second biological replicate, FHV abundance was $2.6 \times$ higher at $24 \mathrm{hpi}$ $(p=0.013)$ and $7.5 \times$ higher at $48 \mathrm{hpi}(p<0.001)$, relative to levels at $0 \mathrm{hpi}$. FHV abundance increased $20 \times(p<0.001)$ at $72 \mathrm{hpi}$ relative to $0 \mathrm{hpi}$, which was the peak of virus infection. Similar to FHV infection in hemocytes, FHV levels in pupal cells was lower at $96 \mathrm{hpi}$ relative to $72 \mathrm{hpi}(p<0.01)$ but was still $15.8 \times$ higher at 96 hpi compared to 0 hpi $(p<0.001)$ (Supplemental Figure S5B). To validate that the increase in FHV abundance was indicative of virus replication, the presence of FHV negative strand was assayed using strand-specific PCR. Active replication of FHV was confirmed by detection of FHV negative-strand PCR product at 72 hpi (Figure 5B). Together, the increase in FHV abundance quantified over the course of infections and the detection of the replicative intermediate form (i.e., negative strand) of FHV demonstrate that primary honey bee cells derived from purple-eyed pupae support the replication of FHV.

The ability to infect mixed cell types derived from honey bee pupae with a model virus helps address some challenges in studying honey bee host-virus interactions using naturally infecting honey bee viruses. FHV can be easily propagated and purified in the lab, which helps circumvent the problem of mixed virus inoculum produced from infected bees, since many honey bee viruses co-purify due to their similar size and the high prevalence of mixed infections in colonies $[10,40,52,63,64,97]$. Since FHV does not naturally infect honey bees, the experimental results may not be confounded by pre-existing infections. However, a limitation of using FHV as a model virus to investigate honey bee antiviral defense mechanisms is that it does not naturally infect honey bees and therefore may not induce the same broad-spectrum antiviral or virus-specific immune responses that occur during infection with a co-evolved virus. One benefit to utilizing FHV in studies aimed at elucidating honey bee antiviral defense is that FHV-host interactions have been studied in a broad range of insect hosts, including mosquitoes, fruit flies, honey bees, tsetse flies, and reduviid bugs, thus facilitating comparative immune studies [105,106,110,111].

\subsection{Flock House Virus Infection Transferred from Infected to Nä̈ve Honey Bee Pupal Cells}

To determine if FHV infection can be transferred from FHV-infected honey bee pupal cells to naïve cells, virus-containing cell culture obtained during peak infection (i.e., $72 \mathrm{hpi}$ ) was transferred to naïve pupal cells. Virus abundance in the secondary host cells was monitored over time. In replicate one, a small volume of FHV-infected pupal cell culture (i.e., $10 \mu \mathrm{L}$ with $2.6 \times 10^{8} \mathrm{FHV}$ RNA copies) was transferred to freshly seeded pupal cells (Figure 6A). FHV abundance at 48 hpi was $15.8 \times$ greater $(p=0.003)$ and at 72 hpi $28 \times$ greater than levels at 0 hpi $(p<0.001)$. In the second replicate, FHV-infected pupal cells (i.e., $10 \mu \mathrm{L}$ infected cell culture with $2.9 \times 10^{8}$ FHV RNA copies) from the first round of infection were transferred to naïve pupal cells, and FHV abundance remained constant from 0 hpi to 48 hpi but was $10.4 \times$ higher at 72 hpi $(p<0.001)$ (Supplemental Figure S6B). As expected, FHV was not detected in control experiments, in which a small volume of mock-infected honey bee pupal cell culture was transferred to naïve cells (Figure 6A and Figure S6B). Together these results confirm that FHV virions produced by primary honey bee pupal cell cultures can be utilized to established new/secondary infections (Figure 6A). 
A

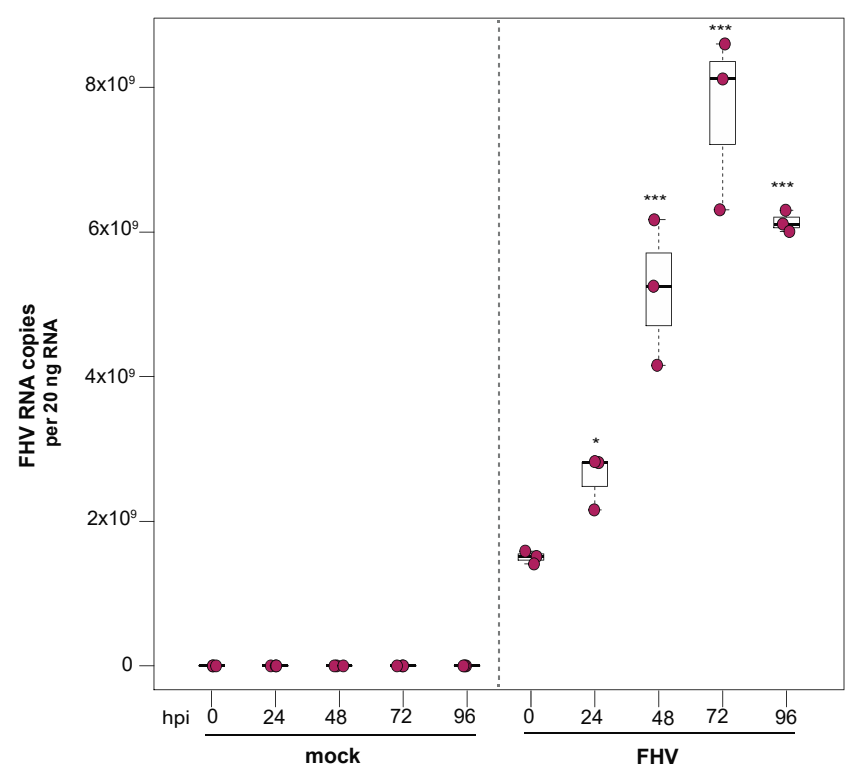

B

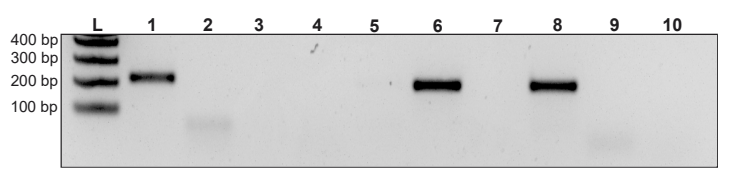

Figure 5. Flock House virus (FHV) replicates in primary honey bee pupal cells. Pupal cells were either mock- or FHV-infected ( $2 \times 10^{8}$ FHV RNA copies), and FHV abundance was quantified over a course of time (i.e., 0 hpi, 24 hpi, 48 hpi, 72 hpi, and 96 hpi). (A) FHV abundance increased at 24 hpi $(1.7 \times, p=0.024)$ and 48 hpi $(3.4 \times p<0.001)$, with a peak in FHV infection at 72 hpi $(5 \times$, $p<0.001$ ), relative to 0 hpi. FHV abundance did not increase from 72 hpi to 96 hpi but remained $4 \times$ higher than at 0 hpi $(p<0.001)$. Raw data are included in Supplemental Table S6. Figure 5 includes results from one representative biological replicate. The data for additional replicates are presented in Supplemental Figure S5. All differences in means relative to 0 hpi were assessed by a Dunnett's test. Significance levels: ${ }^{*} p<0.05 ;{ }^{* * *} p<0.0005$. (B) To validate that the increase in FHV abundance was indicative of virus replication, the presence of the negative strand (replicative intermediate) was assessed by negative-strand-specific RT followed by PCR. The negative strand was detected at $72 \mathrm{hpi}$ (Lane 1). Additional control reactions were performed using pooled RNA from time points 24-96 hpi (Lanes labeled 2-9). Specifically, RNA-isolated FHV containing cell lysate was reversetranscribed with the primer listed below, treated with Exonuclease I to remove excess primer, and amplified using the PCR primers listed for each lane. (L) Molecular weight ladder. (1) 72 hpi RNA template-RT with FHV-TAGS-F, PCR with TAGS and FHV-Rev. (2) Negative control: No RT in the presence of (FHV-TAGS-F), PCR with TAGS and FHV-Rev. (3) Negative control: RT in the presence of (FHV-TAGS-F), PCR with only the FHV-Rev primer. (4) Negative control: RT with random hexamer primer, PCR with TAGS and FHV-Rev. (5) Negative control: No RT enzyme in the presence of random hexamers, PCR with FHV-F and FHV-Rev. (6) Positive control: RT with random hexamers, PCR with FHV-F and FHV-Rev. (7) Negative control: RT with random hexamers, PCR with only FHV-Rev primer. (8) Self-priming: RT without a primer, PCR with FHV-F and FHV-Rev. (9) Negative control: No template, no RT, PCR with TAGS and FHV-Rev. (10) Negative control: No template, no RT, PCR with FHV-F and FHV-Rev. Additional details provided in Supplemental Table S25. 


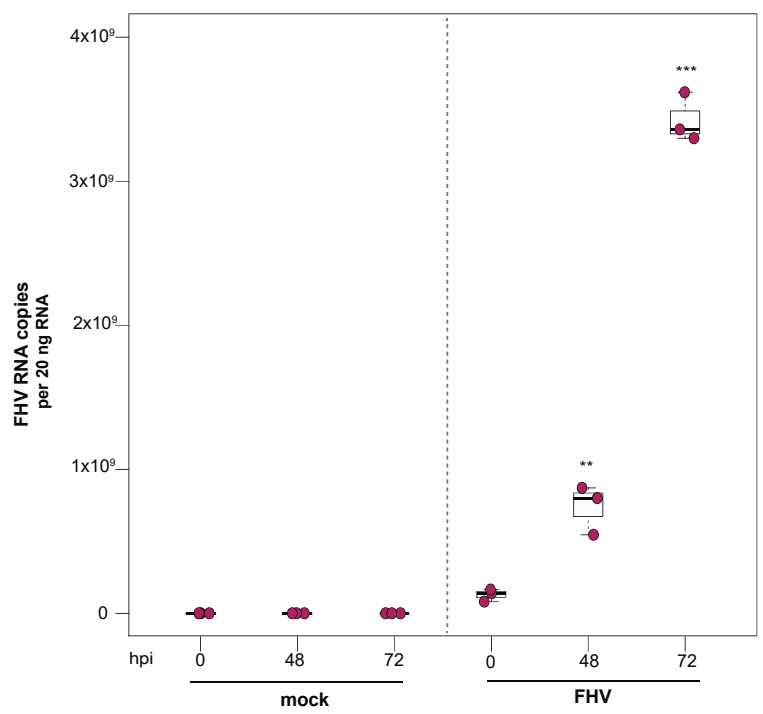

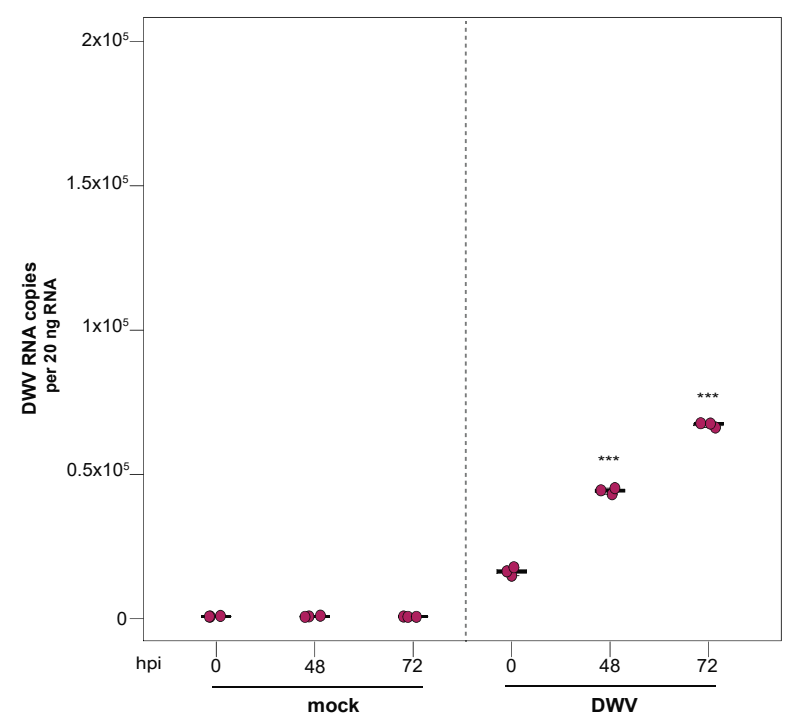

Figure 6. DWV and FHV infection transferred from infected to naïve honey bee pupal cells. To confirm that infectious DWV and FHV virions were produced in infected primary honey bee pupal cells, mock- or virus-infected honey bee pupal cell cultures $(10 \mu \mathrm{L})$ at $72 \mathrm{hpi}$ were transferred to naïve pupal cells. Virus abundance was assessed over a time course (i.e., 0 hpi, 48 hpi, and 72 hpi) using qPCR. Raw data are included in Supplemental Tables S7 and S8. (A) FHV abundance increased $15.8 \times$ at 48 hpi $(p=0.003)$, with a subsequent $28 \times$ increase at 72 hpi relative to 0 hpi $(p<0.001)$. (B) DWV abundance was $2.7 \times(p<0.001)$ higher at 48 hpi and $4.1 \times$ higher at 72 hpi, relative to 0 hpi $(p<0.001)$. Figure 6 includes results from one representative biological replicate. The data for additional replicates are presented in Supplemental Figure S6. All differences in means relative to 0 hpi were assessed by a Dunnett's test. Significance levels: ${ }^{* *} p<0.005 ;{ }^{* * *} p<0.0005$.

\subsection{Deformed Wing Virus Infection Transferred from Infected to Nä̈ve Honey Bee Pupal Cells}

To determine if the DWV-infected cultured primary honey bee pupal cells produced infectious virions, small volumes of DWV-infected cell cultures were transferred to naïve cultured pupal cells. In replicate one, naïve honey bee pupal cells were treated with cells and cell culture supernatant $(10 \mu \mathrm{L})$ from either mock-infected or DWV-infected cultures, which contained an equivalent of $1.04 \times 10^{5}$ DWV RNA copies. By 48 hpi, DWV abundance increased $2.7 \times$ relative to 0 hpi $(p<0.001)$. DWV levels continued to increase over time, with $4.1 \times$ increase at 72 hpi $(p<0.001)$ (Figure 6B). In replicate two, naïve pupal cells were treated with $10 \mu \mathrm{L}$ DWV-infected pupal cells (i.e., $9 \times 10^{4} \mathrm{DWV}$ RNA copies). DWV abundance increased by $2.3 \times$ at $48 \mathrm{hpi}(p<0.01)$ and was $10.4 \times$ greater at $72 \mathrm{hpi}$, relative to 0 hpi $(p<0.001)$ (Supplemental Figure S6D). As expected, DWV was not detected in mock-infected cells, in which a small volume of PBS-treated honey bee pupal cell culture was transferred to naïve cells. The increase in DWV abundance over time and detection of negative strand suggest that the DWV infection in honey bee pupal cells results in the production of infectious DWV virions that have the ability to infect naïve host cells.

\subsection{Immune Gene Expression in Virus-Infected Primary Honey Bee Cells}

Honey bee primary cells will be an important tool to investigate honey bee antiviral defense mechanisms. We hypothesized that differential transcription of immune genes in primary cultures will reflect the transcriptional response in individuals (i.e., pupae or adults) $[86,100,101,107,108,145,146,190]$. Therefore, to begin to characterize cellular-level honey bee antiviral immune responses, honey bee pupal cells were infected with SBV, DWV, or FHV, and the expression of select antiviral genes, including dicer-like (dcr-like), argonaute-2 (ago2), and bee antiviral protein-1 (bap1), which was formerly designated as GenBank MF116383, were analyzed by qPCR in either two or three experimental replicates (Figure 7 and Supplemental Figures S7-S10). 
A

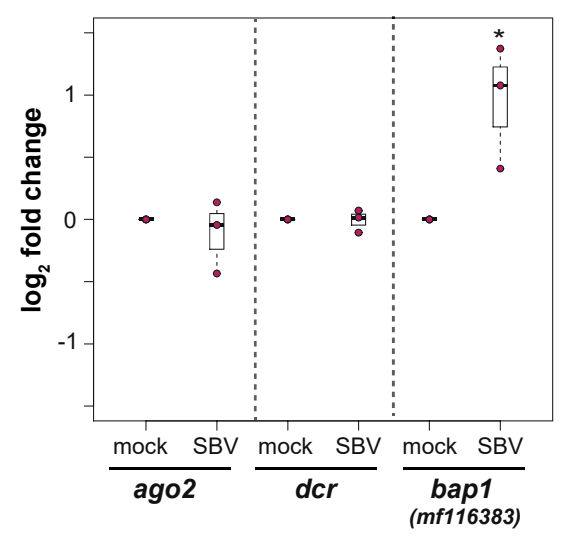

B

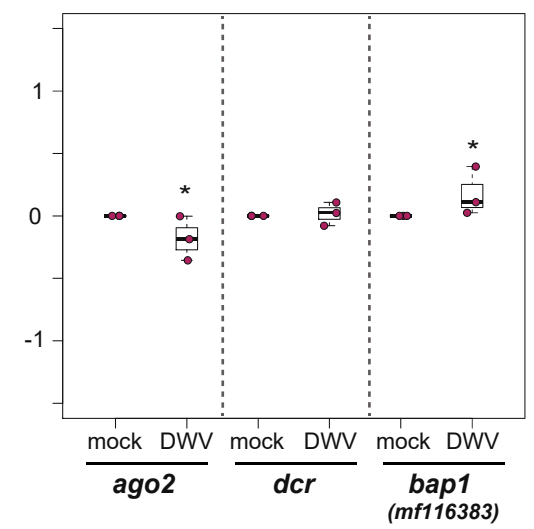

C

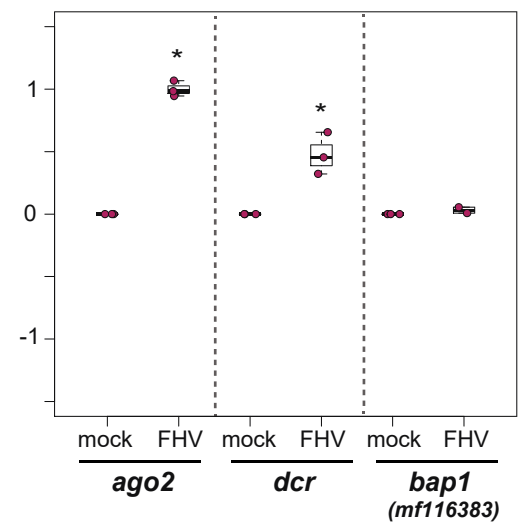

Figure 7. Virus infections of primary honey bee pupal cells differentially impact the expression of select immune genes. The relative expression of three honey bee immune genes, argonaute-2 (ago2), dicer-like (dcr-like), and bee antiviral protein-1 (bap1)/mf116383, were assessed by qPCR at $72 \mathrm{hpi}$. The $\Delta \Delta \mathrm{Ct}$ method with normalization to $r p l 8$ was utilized to assess target gene expression in each sample, and then the $\log _{2}$ fold change values were calculated relative to mock-infected samples. Raw data are included in Supplemental Tables S9-S11. (A) SBV infection of pupal cells did not impact ago2 or dcr-like expression, whereas the expression of bap1 was $0.95 \log _{2}$-fold greater at $72 \mathrm{hpi}(p=0.032)$. (B) DWV-infected pupal cells exhibited slightly lower ago2 expression $(p=0.032)$ relative to mock-infected cells at $72 \mathrm{hpi}$, whereas there was no impact of virus infection on dcr-like expression. The expression of bap1 was $0.18 \log _{2}$-fold higher in DWV-infected pupal cells compared to mock-infected cells at 72 hpi $(p=0.032)$. (C) In pupal cells infected with FHV, ago2 and dcr-like expression was higher (i.e., 1 and $0.48 \log _{2}$-fold change, respectively, $p=0.032$ ) in FHV-infected cells relative to mock-infected cells at 72 hpi. The expression of bap1 was not impacted by FHV infection. The differences in $\log _{2}$ immune gene relative expression in infected cells relative to mock-infected (PBS-treated) cells at 72 hpi were assessed using a one-sided Wilcoxon Rank Sums test. Significance level: ${ }^{*} p<0.05$.

Overall, the expression of bap1 (GenBank: MF116383) was greater in SBV-infected cells than mock-infected pupal cells at $72 \mathrm{hpi}$. Specifically, in first biological replicate, bap 1 expression was $0.67 \log _{2}$-fold greater in SBV-infected pupal cells relative to the expression level in mock-infected cells (Wilcoxon Rank Sums, $p=0.032$ ) (Supplemental Figure S7C). Likewise, bap 1 expression was greater in the second biological replication $\left(0.95 \log _{2}\right.$-fold, $p=0.032$, Figure 7A) but not the third. Since the bap1 expression was greater two of the three biological replicates of SBV-infected pupal cells, its expression in the third biological replicate was also assessed at $96 \mathrm{hpi}$, at which time its expression was $0.73 \log _{2}$-fold higher in SBV-infected cells relative to mock-infected cells $(p=0.032)$ (Supplemental Figure S7C). Expression of neither ago2 nor dcr-like were appreciably impacted by SBV infection. Specifically, ago 2 was not differentially expressed in the first two replicates but had $-0.76 \log _{2}$-fold lower expression in the third replicate $(p=0.032)$ (Figure 7A and Figure S7A). Similarly, dcr-like was not differentially expressed in the second replicate but exhibited $-0.67 \log _{2}$-fold lower expression in the third replicate $(p=0.032)$ (Supplemental Figure S7). In DWV-infected pupal cells, bap1 expression was unchanged in one replicate (Supplemental Figure S8C) and slightly greater in the second experimental replicate relative to mock-infected cells at $72 \mathrm{hpi}\left(0.18 \log _{2}\right.$-fold change, $p=0.032$, Figure $\left.7 \mathrm{~B}\right)$. In DWVinfected pupal cells, ago2 expression was slightly lower compared to mock-infected cells in two biological replicates $\left(-0.28\right.$ and $-0.18 \log _{2}$-fold change, $p=0.032$, Figure $7 \mathrm{~B}$ and Figure S8A). In contrast, dcr-like expression was slightly lower in DWV-infected pupal cells in one replicate $\left(-0.26 \log _{2}\right.$-fold, $p=0.032$, Figure S8B), while its expression was similar to mock-infected cells in another replicate (Supplemental Figure S7B). The expression of bap1 was not appreciably impacted by FHV infection of pupal cells (Figure 7C and Figure S9C). Specifically, bap1 expression was slightly lower in one replicate $\left(-0.4 \log _{2}\right.$-fold, $\left.p=0.032\right)$ and unchanged in the second replicate, compared to mock-infected cells (Figure 7C and Figure S9C). Interestingly, ago2 expression was consistently higher in FHV-infected cells 
relative to mock-infected cells in two replicates (i.e., $1 \log _{2}$-fold in rep1 and $1 \log _{2}$-fold in rep2, $p=0.032$ ) (Figure 7C and Figure S9A). Similarly, dcr-like expression was greater in FHV-infected cells relative to mock-infected cells in both replicates (i.e., $0.66 \log _{2}$-fold in rep1 and $0.48 \log _{2}$-fold in rep2, $p=0.032$ ) (Figure $7 \mathrm{C}$ and Figure S9B). The trends in immune gene expression in FHV-infected hemocytes were similar to FHV-infected pupal cells (Supplemental Figure S10). Specifically, bap1 expression was similar in FHV-infected and mock-infected cells at $72 \mathrm{hpi}$, whereas FHV-infected hemocytes exhibited greater ago 2 (i.e., $1.1 \log _{2}$-fold in rep1 and $0.54 \log _{2}$-fold in rep2, $p=0.032$ ) and $d c r$-like expression (i.e., $0.45 \log _{2}$-fold in rep1 and $0.63 \log _{2}$-fold in rep2, $p=0.032$ ) than mock-infected hemocytes in both biological replicates (Supplemental Figure S10).

Together these experiments indicate that studies in cultured honey bee primary cells recapitulate data obtained from transcriptome level studies in individual honey bees, including those carried out in pupae and adult bees [100], though additional studies are needed to better assess honey bee antiviral immune responses at the cellular level. Further development, including the advancements described herein, and utilization of honey bee primary cells is integral to elucidating the defense pathways important for specific virus infections and, in turn, identifying viral counter defense strategies.

\section{Conclusions}

In summary, these data indicate that primary honey bee cell cultures of larval hemocytes and explanted pupal tissue serve as a useful tool for studying honey bee-host interactions. In addition to demonstrating that a panel of viruses (SBV, DWV, and FHV) replicates in hemocytes and/or pupal cells, pupal cell cultures showed virus-specific transcriptional regulation of three immune genes (dcr-like, ago2, and bap1). These cultures can be established using rather simple techniques that are amenable to higher sample size studies. Future work to optimize transfection in these different cell culture types will be paramount for performing more advanced mechanistic studies. This includes utilizing RNAi-mediated gene knockdown, which facilitates the study of honey bee host-virus interactions by directly demonstrating the importance of specific genes in limiting particular viruses. For example, this study indicates that hemocytes are a natural site of infection for SBV and that SBV results in higher bap1 expression in infected pupal cells. By reducing the expression of bap 1 in cell cultures that are infected with SBV, one could test the hypothesis that this gene is important for cells to combat SBV infection. Additionally, the use of cell culture will facilitate the study of basic virological questions, including virus cellular tropism, entry, and uncoating mechanisms. Additional efforts to establish virus-free cell lines from explanted honey bee tissues will prove useful for the production of pure virus stocks, especially in concert with the development of cDNA clones capable of producing infectious virus. The data presented in this study represent one of many steps toward the development of sophisticated cell culture techniques for the study of honey bee host-virus interactions.

Supplementary Materials: The following are available online at https:/ / www.mdpi.com/article/10.3 390/insects12070653/s1, Excel file with Supplementary Tables S1-S24, and Supplemental Figures S1-S12. Supplemental Table and Supplemental Figure titles are listed below: Supplemental Table S1. Primers used in this study. Supplemental Table S2. Raw data for SBV-infected hemocytes (Figure 1). Supplemental Table S3. Raw data for SBV-infected purple-eyed pupal cells (Figure 2 and Figure S2). Supplemental Table S4. Raw data for DWV-infected purple-eyed pupal cells (Figure 3 and Figure S3). Supplemental Table S5. Raw data for FHV-infected hemocytes (Figure 4 and Figure S4). Supplemental Table S6. Raw data for FHV-infected purple-eyed pupal cells (Figure 5 and Figure S5). Supplemental Table S7. Raw data for transfer of DWV infection from DWV-infected purple-eyed pupal cells to naïve purple-eyed pupal cell (Figure 6 and Figure S6). Supplemental Table S8. Raw data for transfer of FHV infection from FHV-infected purple-eyed pupal cells to naïve purple-eyed pupal cells (Figure 6 and Figure S6). Supplemental Table S9. Raw Ct values for immune gene expression in SBV-infected pupal cells (Figure 7 and Figure S7). Supplemental Table S10. Raw data for immune gene expression in DWV-infected honey bee pupal cells (Figure 7 and Figure S8). Supplemental Table S11. Raw data 
for immune gene expression in FHV-infected honey bee pupal cells (Figure 7 and Figure S9). Supplemental Table S12. Raw data for immune gene expression in FHV-infected hemocytes (Figure S10). Supplemental Table S13. SBV fold change relative to 0 hpi in hemocytes. Supplemental Table S14. SBV fold change relative to 0 hpi in pupal cells. Supplemental Table S15. DWV fold change relative to 0 hpi in purple-eyed pupal cells. Supplemental Table S16. FHV fold change relative to 0 hpi in hemocytes. Supplemental Table S17. FHV fold change relative to 0 hpi in purple-eyed pupal cells. Supplemental Table S18. DWV fold change relative to 0 hpi in naïve pupal cells treated with material from infected cells. Supplemental Table S19. FHV fold change relative to 0 hpi in naïve pupal cells treated with material from infected cells. Supplemental Table S20. Fold change and $p$-values for immune genes in SBV-infected pupae. Supplemental Table S21. Immune gene fold change and $p$-values for DWV-infected honey bee pupal cells. Supplemental Table S22. Immune gene fold change and $p$-values for FHV-infected honey bee pupal cells. Supplemental Table S23. Immune gene fold change and $p$-values for FHV-infected hemocytes. Supplemental Table S24. Virus testing in corresponding honey bee larval carcass and hemocyte samples indicate that hemocytes are natural sites of infection for black queen cell virus (BQCV). Supplemental Table S25. Negative strand-specific RT-PCR confirms viral replication in hemocytes and pupal cells. Supplemental Figure S1. Larval hemocyte cultures have relatively few contaminating adipocytes. Supplemental Figure S2. Sacbrood virus (SBV) replicates in primary honey bee pupal cell cultures. Supplemental Figure S3. Deformed wing virus (DWV) replicates in primary honey bee pupal cell cultures. Supplemental Figure S4. Flock House virus (FHV) replicates in primary honey bee hemocytes. Supplemental Figure S5. Flock House virus (FHV) replicates in primary honey bee pupal cells. Supplemental Figure S6. DWV and FHV infection transferred from infected to naïve honey bee pupal cells. Supplemental Figure S7. Infection of primary pupal cells with SBV results in higher bap-1 expression. Supplemental Figure S8. Infection of primary honey bee pupal cells with DWV has modest impact on the expression of select immune genes. Supplemental Figure S9. Infection of primary honey bee pupal cells with FHV results in differential regulation of immune genes. Supplemental Figure S10. Infection of honey bee hemocytes with FHV results in differential regulation of immune genes. Supplemental Figure S11. Sacbrood virus (SBV) inoculum was free of several other common honey bee infecting viruses. Supplemental Figure S12. Deformed wing virus (DWV) inoculum was free of several other common honey bee infecting viruses.

Author Contributions: Conceptualization, A.J.M., F.P. and M.L.F.; methodology, A.J.M., F.P., V.L. and M.L.F.; formal analysis A.J.M., F.P. and M.L.F.; investigation, A.J.M., F.P. and M.L.F.; resources, M.L.F.; data curation, A.J.M., F.P. and M.L.F.; writing-original draft preparation, A.J.M., F.P. and M.L.F.; writing—review and editing, A.J.M., F.P., V.L. and M.L.F.; visualization, A.J.M., F.P. and M.L.F.; supervision, M.L.F.; project administration, M.L.F.; funding acquisition, M.L.F. All authors have read and agreed to the published version of the manuscript.

Funding: Research in the Flenniken laboratory is supported by the National Science Foundation CAREER Program (Award Number 1651561), Agriculture and Food Research Initiative (USDA-NIFAAFRI) program, Montana Department of Agriculture Specialty Crop Block Grant Program (Award Number 17SC003108), USDA-NIFA Hatch Multistate Funding (NC-1173), and Project Apis m.-Costco Scholar Fellowship Program for Honey Bee Health. The funders had no role in study design, data collection and analysis, decision to publish, or preparation of this manuscript.

Institutional Review Board Statement: Ethical review and approval were waived for this study, since the study involved only the use of invertebrate animals (i.e., honey bees), and Biosafety Protocols and Standard Operating Procedures were approved by Montana State University's Biosafety Committee (Approval Date: June 2020; Protocol Number: 2020-5-19).

Data Availability Statement: The majority of the data generated or analyzed during this study are included in this published article and its Supplementary Material files (available online). Additional data are available from the corresponding author upon request.

Acknowledgments: We are grateful to Marie Pizzorno for help with producing the DWV stock, Katie F. Daughenbaugh for discussions throughout the experiments, and Matthew Taylor for assistance with honey bee hemocyte imaging. We would also like to thank the members of Flenniken laboratory (Brian Ross and Naomi Kaku) for reviewing this manuscript prior to publication. 
Conflicts of Interest: The authors declare no conflict of interest. The funders had no role in the design of the study; in the collection, analyses, or interpretation of data; in the writing of the manuscript; or in the decision to publish the results.

\section{References}

1. $\quad$ van Cleef, K.W.R.; van Mierlo, J.T.; van den Beek, M.; van Rij, R.P. Identification of Viral Suppressors of RNAi by a Reporter Assay in Drosophila S2 Cell Culture. In Antiviral RNAi: Concepts, Methods, and Applications; van Rij, R.P., Ed.; Humana Press: Totowa, NJ, USA, 2011; pp. 201-213.

2. Baum, B.; Cherbas, L. Drosophila Cell Lines as Model Systems and as an Experimental Tool. In Drosophila: Methods and Protocols; Dahmann, C., Ed.; Humana Press: Totowa, NJ, USA, 2008; pp. 391-424.

3. Harschnitz, O.; Studer, L. Human stem cell models to study host-virus interactions in the central nervous system. Nat. Rev. Immunol. 2021, 21, 441-453. [CrossRef] [PubMed]

4. Hahn, C.S.; Hahn, Y.S.; Braciale, T.J.; Rice, C.M. Infectious Sindbis virus transient expression vectors for studying antigen processing and presentation. Proc. Natl. Acad. Sci. USA 1992, 89, 2679. [CrossRef] [PubMed]

5. Genzel, Y.; Reichl, U. Vaccine Production. In Animal Cell Biotechnology: Methods and Protocols; Pörtner, R., Ed.; Humana Press: Totowa, NJ, USA, 2007; pp. 457-473.

6. Montagnon, B.J.; Fanget, B.; Vincent-Falquet, J.C. Industrial-scale production of inactivated poliovirus vaccine prepared by culture of Vero cells on microcarrier. Rev. Infect. Dis. 1984, 6 (Suppl. 2), S341-S344. [CrossRef] [PubMed]

7. Hudu, S.A.; Alshrari, A.S.; Syahida, A.; Sekawi, Z. Cell Culture, Technology: Enhancing the Culture of Diagnosing Human Diseases. J. Clin. Diagn. Res. 2016, 10, DE01-DE05. [CrossRef]

8. Guo, Y.; Goodman, C.L.; Stanley, D.W.; Bonning, B.C. Cell Lines for Honey Bee Virus Research. Viruses 2020, 12, 236. [CrossRef] [PubMed]

9. Goblirsch, M.J.; Spivak, M.S.; Kurtti, T.J. A Cell Line Resource Derived from Honey Bee (Apis mellifera) Embryonic Tissues. PLoS ONE 2013, 8, e09831. [CrossRef]

10. Carrillo-Tripp, J.; Dolezal, A.G.; Goblirsch, M.J.; Miller, W.A.; Toth, A.L.; Bonning, B.C. In vivo and in vitro infection dynamics of honey bee viruses. Sci. Rep. 2016, 6, 22265. [CrossRef]

11. vanEngelsdorp, D.; Caron, D.; Hayes, J.; Underwood, R.; Henson, M.; Rennich, K.; Spleen, A.; Andree, M.; Snyder, R.; Lee, K.; et al. A national survey of managed honey bee 2010-11 winter colony losses in the USA: Results from the Bee Informed Partnership. J. Apic. Res. 2012, 51, 115-124. [CrossRef]

12. Spleen, A.M.; Lengerich, E.J.; Rennich, K.; Caron, D.; Rose, R.; Pettis, J.S.; Henson, M.; Wilkes, J.T.; Wilson, M.; Stitzinger, J.; et al. A national survey of managed honey bee 2011-12 winter colony losses in the United States: Results from the Bee Informed Partnership. J. Apic. Res. 2013, 52, 44-53. [CrossRef]

13. Steinhauer, N.A.; Rennich, K.; Wilson, M.E.; Caron, D.M.; Lengerich, E.J.; Pettis, J.S.; Rose, R.; Skinner, J.A.; Tarpy, D.R.; Wilkes, J.T.; et al. A national survey of managed honey bee 2012-2013 annual colony losses in the USA: Results from the Bee Informed Partnership. J. Apic. Res. 2014, 53, 1-18. [CrossRef]

14. Seitz, N.; Traynor, K.S.; Steinhauer, N.; Rennich, K.; Wilson, M.E.; Ellis, J.D.; Rose, R.; Tarpy, D.R.; Sagili, R.R.; Caron, D.M.; et al. A national survey of managed honey bee 2014-2015 annual colony losses in the USA. J. Apic. Res. 2015, 54, 292-304. [CrossRef]

15. Kulhanek, K.; Steinhauer, N.; Rennich, K.; Caron, D.M.; Sagili, R.R.; Pettis, J.S.; Ellis, J.D.; Wilson, M.E.; Wilkes, J.T.; Tarpy, D.R.; et al. A national survey of managed honey bee 2015-2016 annual colony losses in the USA. J. Apic. Res. 2017, 56, 328-340. [CrossRef]

16. Traynor, K.S.; Rennich, K.; Forsgren, E.; Rose, R.; Pettis, J.; Kunkel, G.; Madella, S.; Evans, J.; Lopez, D.; vanEngelsdorp, D. Multiyear survey targeting disease incidence in US honey bees. Apidologie 2016, 47, 325-347. [CrossRef]

17. Steinhauer, N.; Rennich, K.; Caron, D.M.; Ellis, J.D.; Koenig, P.; Kulhanek, K.; Klepps, J.; Lee, K.; Milbrath, M.; Rangel, J.R.; et al. Honey Bee Colony Losses 2016-2017: Preliminary Results; Bee Informed Partnership. 2017. Available online: https: / beeinformed.org/2017/05/25/2016-2017-loss-results-thank-you-to-all-survey-participants / (accessed on 27 June 2021).

18. Bruckner, S.; Steinhauer, N.; Rennich, K.; Aurell, D.D.; Caron, D.M.; Ellis, J.D.; Fauvel, A.M.; Kulhanek, K.; Nelson, K.C.; Rangel, J.; et al. United States Honey Bee Colony Losses 2017-2018: Preliminary Results; Bee Informed Partnership. 2018. Available online: https: / / beeinformed.org/2018/06/21/preliminary-results-2017-2018-total-and-average-honey-bee-colony-losses-bystate-and-the-district-of-columbia/ (accessed on 27 June 2021).

19. Bruckner, S.; Steinhauer, N.; Aurell, S.D.; Caron, D.M.; Ellis, J.D.; Fauvel, A.M.; Kulhanek, K.; McArt, S.H.; Mullen, E.; Rangel, J.; et al. 2018-2019 Honey Bee Colony Losses in the United States: Preliminary Results; Bee Informed Partnership. 2019. Available online: https: / / beeinformed.org/ citizen-science/loss-and-management-survey/ (accessed on 27 June 2021).

20. Goulson, D.; Nicholls, E.; Botias, C.; Rotheray, E.L. Bee declines driven by combined stress from parasites, pesticides, and lack of flowers. Science 2015, 347, 1255957. [CrossRef]

21. Cornman, R.S.; Tarpy, D.R.; Chen, Y.; Jeffreys, L.; Lopez, D.; Pettis, J.S.; VanEngelsdorp, D.; Evans, J.D. Pathogen webs in collapsing honey bee colonies. PLoS ONE 2012, 7, e43562. [CrossRef]

22. Brutscher, L.M.; McMenamin, A.J.; Flenniken, M.L. The buzz about honey bee viruses. PLoS Pathog. 2016, 12, e1005757. [CrossRef]

23. Grozinger, C.M.; Flenniken, M.L. Bee Viruses: Ecology, Pathogenicity, and Impacts. Annu. Rev. Entomol. 2019, 64, 205-226. [CrossRef] 
24. McMenamin, A.J.; Flenniken, M.L. Recently identified bee viruses and their impact on bee pollinators. Curr. Opin. Insect Sci. 2018, 26, 120-129. [CrossRef]

25. Schwarz, R.S.; Bauchan, G.R.; Murphy, C.A.; Ravoet, J.; de Graaf, D.C.; Evans, J.D. Characterization of two species of trypanosomatidae from the honey bee Apis mellifera: Crithidia mellificae langridge and mcghee, and lotmaria passim n. gen., n. sp. J. Eukaryot. Microbiol. 2015, 62, 1-17. [CrossRef]

26. Runckel, C.; DeRisi, J.; Flenniken, M.L. A draft genome of the honey bee trypanosomatid parasite crithidia mellificae. PLoS ONE 2014, 9, e95057. [CrossRef] [PubMed]

27. Ravoet, J.; Schwarz, R.S.; Descamps, T.; Yañez, O.; Tozkar, C.O.; Martin-Hernandez, R.; Bartolomé, C.; De Smet, L.; Higes, M.; Wenseleers, T.; et al. Differential diagnosis of the honey bee trypanosomatids Crithidia mellificae and Lotmaria passim. J. Invertebr. Pathol. 2015, 130, 21-27. [CrossRef]

28. Cornman, R.S.; Chen, Y.P.; Schatz, M.C.; Street, C.; Zhao, Y.; Desany, B.; Egholm, M.; Hutchison, S.; Pettis, J.S.; Lipkin, W.I.; et al. Genomic Analyses of the Microsporidian Nosema ceranae, an Emergent Pathogen of Honey Bees. PLoS Pathog. 2009,5 , e1000466. [CrossRef]

29. Genersch, E. American Foulbrood in honeybees and its causative agent, Paenibacillus larvae. J. Invertebr. Pathol. 2010, 103, S10-S19. [CrossRef]

30. Forsgren, E. European foulbrood in honey bees. J. Invertebr. Pathol. 2010, 103, S5-S9. [CrossRef]

31. Nazzi, F.; Le Conte, Y. Ecology of Varroa destructor, the Major Ectoparasite of the Western Honey Bee, Apis mellifera. Annu. Rev. Entomol. 2016, 61, 417-432. [CrossRef] [PubMed]

32. Beaurepaire, A.; Piot, N.; Doublet, V.; Antunez, K.; Campbell, E.; Chantawannakul, P.; Chejanovsky, N.; Gajda, A.; Heerman, M.; Panziera, D.; et al. Diversity and Global Distribution of Viruses of the Western Honey Bee, Apis mellifera. Insects 2020, 11, 239. [CrossRef]

33. Daughenbaugh, K.F.; Kahnonitch, I.; Carey, C.C.; McMenamin, A.J.; Wiegand, T.; Erez, T.; Arkin, N.; Ross, B.; Wiedenheft, B.; Sadeh, A.; et al. Metatranscriptome Analysis of Sympatric Bee Species Identifies Bee Virus Variants and a New Virus, Andrena-Associated Bee Virus-1. Viruses 2021, 13, 291. [CrossRef]

34. Schoonvaere, K.; Smagghe, G.; Francis, F.; de Graaf, D.C. Study of the Metatranscriptome of Eight Social and Solitary Wild Bee Species Reveals Novel Viruses and Bee Parasites. Front. Microbiol. 2018, 9, 177. [CrossRef]

35. de Miranda, J.R.; Cornman, R.S.; Evans, J.D.; Semberg, E.; Haddad, N.; Neumann, P.; Gauthier, L. Genome Characterization, Prevalence and Distribution of a Macula-Like Virus from Apis mellifera and Varroa destructor. Viruses 2015, 7, $3586-3602$. [CrossRef] [PubMed]

36. Remnant, E.J.; Shi, M.; Buchmann, G.; Blacquiere, T.; Holmes, E.C.; Beekman, M.; Ashe, A. A Diverse Range of Novel RNA Viruses in Geographically Distinct Honey Bee Populations. J. Virol. 2017, 91, e00158-17. [CrossRef]

37. Levin, S.; Sela, N.; Chejanovsky, N. Two novel viruses associated with the Apis mellifera pathogenic mite Varroa destructor. Sci. Rep. 2016, 6, 37710. [CrossRef]

38. Levin, S.; Galbraith, D.; Sela, N.; Erez, T.; Grozinger, C.M.; Chejanovsky, N. Presence of Apis Rhabdovirus-1 in Populations of Pollinators and Their Parasites from Two Continents. Front. Microbiol. 2017, 8, 2482. [CrossRef]

39. Galbraith, D.A.; Fuller, Z.L.; Ray, A.M.; Brockmann, A.; Frazier, M.; Gikungu, M.W.; Martinez, J.F.I.; Kapheim, K.M.; Kerby, J.T.; Kocher, S.D.; et al. Investigating the viral ecology of global bee communities with high-throughput metagenomics. Sci. Rep. 2018, 8, 8879. [CrossRef] [PubMed]

40. Runckel, C.; Flenniken, M.L.; Engel, J.C.; Ruby, J.G.; Ganem, D.; Andino, R.; DeRisi, J.L. Temporal Analysis of the Honey Bee Microbiome Reveals Four Novel Viruses and Seasonal Prevalence of Known Viruses, Nosema, and Crithidia. PLoS ONE 2011, 6, e20656. [CrossRef] [PubMed]

41. Deboutte, W.; Beller, L.; Yinda, C.K.; Shi, C.; Smets, L.; Vanmechelen, B.; Conceição-Neto, N.; Dallmeier, K.; Maes, P.; de Graaf, D.C.; et al. Hymenoptera associated eukaryotic virome lacks host specificity. bioRxiv 2020. [CrossRef]

42. Govan, V.A.; Leat, N.; Allsopp, M.; Davison, S. Analysis of the Complete Genome Sequence of Acute Bee Paralysis Virus Shows That It Belongs to the Novel Group of Insect-Infecting RNA Viruses. Virology 2000, 277, 457-463. [CrossRef]

43. Leat, N.; Ball, B.; Govan, V.; Davison, S. Analysis of the complete genome sequence of black queen-cell virus, a picorna-like virus of honey bees. J. Gen. Virol. 2000, 81, 2111-2119. [CrossRef]

44. Olivier, V.; Blanchard, P.; Chaouch, S.; Lallemand, P.; Schurr, F.; Celle, O.; Dubois, E.; Tordo, N.; Thiéry, R.; Houlgatte, R.; et al. Molecular characterisation and phylogenetic analysis of Chronic bee paralysis virus, a honey bee virus. Virus Res. 2008, 132, 59-68. [CrossRef]

45. Ribière, M.; Olivier, V.; Blanchard, P. Chronic bee paralysis: A disease and a virus like no other? J. Invertebr. Pathol. 2010, 103, S120-S131. [CrossRef]

46. Lanzi, G.; de Miranda, J.R.; Boniotti, M.B.; Cameron, C.E.; Lavazza, A.; Capucci, L.; Camazine, S.M.; Rossi, C. Molecular and biological characterization of deformed wing virus of honeybees (Apis mellifera L.). J. Virol. 2006, 80, 4998-5009. [CrossRef]

47. de Miranda, J.R.; Genersch, E. Deformed wing virus. J. Invertebr. Pathol. 2010, 103, S48-S61. [CrossRef] [PubMed]

48. Maori, E.; Lavi, S.; Mozes-Koch, R.; Gantman, Y.; Peretz, Y.; Edelbaum, O.; Tanne, E.; Sela, I. Isolation and characterization of Israeli acute paralysis virus, a dicistrovirus affecting honeybees in Israel: Evidence for diversity due to intra- and inter-species recombination. J. Gen. Virol. 2007, 88, 3428-3438. [CrossRef] 
49. de Miranda, J.R.; Drebot, M.; Tyler, S.; Shen, M.; Cameron, C.E.; Stoltz, D.B.; Camazine, S.M. Complete nucleotide sequence of Kashmir bee virus and comparison with acute bee paralysis virus. J. Gen. Virol. 2004, 85, 2263-2270. [CrossRef] [PubMed]

50. Ghosh, R.C.; Ball, B.V.; Willcocks, M.M.; Carter, M.J. The nucleotide sequence of sacbrood virus of the honey bee: An insect picorna-like virus. J. Gen. Virol. 1999, 80, 1541-1549. [CrossRef]

51. Bigot, D.; Dalmon, A.; Roy, B.; Hou, C.; Germain, M.; Romary, M.; Deng, S.; Diao, Q.; Weinert, L.A.; Cook, J.M.; et al. The discovery Halictivirus resolves the Sinaivirus phylogeny. J. Gen. Virol. 2017, 98, 2864-2875. [CrossRef]

52. Daughenbaugh, K.F.; Martin, M.; Brutscher, L.M.; Cavigli, I.; Garcia, E.; Lavin, M.; Flenniken, M.L. Honey bee infecting Lake Sinai viruses. Viruses 2015, 7, 3285-3309. [CrossRef] [PubMed]

53. Francis, R.M.; Nielsen, S.L.; Kryger, P. Patterns of viral infection in honey bee queens. J. Gen. Virol. 2013, 94, 668-676. [CrossRef]

54. D'Alvise, P.; Seeburger, V.; Gihring, K.; Kieboom, M.; Hasselmann, M. Seasonal dynamics and co-occurrence patterns of honey bee pathogens revealed by high-throughput RT-qPCR analysis. Ecol. Evol. 2019, 9, 10241-10252. [CrossRef] [PubMed]

55. Allen, M.; Ball, B. The incidence and world distribution of honey bee viruses. Bee World 1996, 77, 141-162. [CrossRef]

56. Bradbear, N. World Distribution of Major Honeybee Diseases and Pests. Bee World 1988, 69, 15-39. [CrossRef]

57. Ellis, J.D.; Munn, P.A. The worldwide health status of honey bees. Bee World 2005, 86, 88-101. [CrossRef]

58. Chen, Y.P.; Siede, R. Honey bee viruses. Adv. Virus Res. 2007, 70, 33-80. [CrossRef] [PubMed]

59. Bailey, L. The multiplication and spread of sacbrood virus of bees. Ann. Appl. Biol. 1969, 63, 483-491. [CrossRef]

60. Shen, M.; Cui, L.; Ostiguy, N.; Cox-Foster, D. Intricate transmission routes and interactions between picorna-like viruses (Kashmir bee virus and sacbrood virus) with the honeybee host and the parasitic varroa mite. J. Gen. Virol. 2005, 86, 2281-2289. [CrossRef] [PubMed]

61. Bailey, L.; Ball, B.V.; Perry, J.N. The prevalence of viruses of honey bees in Britain. Ann. Appl. Biol. 1981, 97, 109-118. [CrossRef]

62. Tentcheva, D.; Gauthier, L.; Zappulla, N.; Dainat, B.; Cousserans, F.; Colin, M.E.; Bergoin, M. Prevalence and seasonal variations of six bee viruses in Apis mellifera L. and Varroa destructor mite populations in France. Appl. Environ. Microbiol. 2004, 70, 7185-7191. [CrossRef] [PubMed]

63. Faurot-Daniels, C.; Glenny, W.; Daughenbaugh, K.F.; McMenamin, A.J.; Burkle, L.A.; Flenniken, M.L. Longitudinal monitoring of honey bee colonies reveals dynamic nature of virus abundance and indicates a negative impact of Lake Sinai virus 2 on colony health. PLOS ONE 2020, 15, e0237544. [CrossRef]

64. Cavigli, I.; Daughenbaugh, K.F.; Martin, M.; Lerch, M.; Banner, K.; Garcia, E.; Brutscher, L.M.; Flenniken, M.L. Pathogen prevalence and abundance in honey bee colonies involved in almond pollination. Apidologie 2016, 47, 251-266. [CrossRef] [PubMed]

65. Gusachenko, O.N.; Woodford, L.; Balbirnie-Cumming, K.; Campbell, E.M.; Christie, C.R.; Bowman, A.S.; Evans, D.J. Green Bees: Reverse Genetic Analysis of Deformed Wing Virus Transmission, Replication, and Tropism. Viruses 2020, 12, 532. [CrossRef]

66. Gisder, S.; Aumeier, P.; Genersch, E. Deformed wing virus: Replication and viral load in mites (Varroa destructor). J. Gen. Virol. 2009, 90, 463-467. [CrossRef]

67. Genersch, E.; Yue, C.; Fries, I.; de Miranda, J.R. Detection of Deformed wing virus, a honey bee viral pathogen, in bumble bees (Bombus terrestris and Bombus pascuorum) with wing deformities. J. Invertebr. Pathol. 2006, 91, 61-63. [CrossRef]

68. Moeckel, N.; Gisder, S.; Genersch, E. Horizontal transmission of deformed wing virus: Pathological consequences in adult bees (Apis mellifera) depend on the transmission route. J. Gen. Virol. 2011, 92, 370-377. [CrossRef]

69. Benaets, K.; Van Geystelen, A.; Cardoen, D.; De Smet, L.; de Graaf, D.C.; Schoofs, L.; Larmuseau, M.H.D.; Brettell, L.E.; Martin, S.J.; Wenseleers, T. Covert deformed wing virus infections have long-term deleterious effects on honeybee foraging and survival. Proc. R. Soc. B Biol. Sci. 2017, 284, 20162149. [CrossRef]

70. Dainat, B.; Evans, J.D.; Chen, Y.P.; Gauthier, L.; Neumann, P. Dead or alive: Deformed wing virus and Varroa destructor reduce the life span of winter honeybees. Appl. Environ. Microbiol. 2012, 78, 981-987. [CrossRef]

71. Traniello, I.M.; Bukhari, S.A.; Kevill, J.; Ahmed, A.C.; Hamilton, A.R.; Naeger, N.L.; Schroeder, D.C.; Robinson, G.E. Meta-analysis of honey bee neurogenomic response links Deformed wing virus type A to precocious behavioral maturation. Sci. Rep. 2020, 10, 3101. [CrossRef] [PubMed]

72. Wells, T.; Wolf, S.; Nicholls, E.; Groll, H.; Lim, K.S.; Clark, S.J.; Swain, J.; Osborne, J.L.; Haughton, A.J. Flight performance of actively foraging honey bees is reduced by a common pathogen. Environ. Microbiol. Rep. 2016, 8, 728-737. [CrossRef] [PubMed]

73. Fujiyuki, T.; Takeuchi, H.; Ono, M.; Ohka, S.; Sasaki, T.; Nomoto, A.; Kubo, T. Novel Insect Picorna-Like Virus Identified in the Brains of Aggressive Worker Honeybees. J. Virol. 2004, 78, 1093-1100. [CrossRef] [PubMed]

74. Iqbal, J.; Mueller, U. Virus infection causes specific learning deficits in honeybee foragers. Proc. Biol. Sci. 2007, $274,1517-1521$. [CrossRef] [PubMed]

75. Pizzorno, M.C.; Field, K.; Kobokovich, A.L.; Martin, P.L.; Gupta, R.A.; Mammone, R.; Rovnyak, D.; Capaldi, E.A. Transcriptomic Responses of the Honey Bee Brain to Infection with Deformed Wing Virus. Viruses 2021, 13, 287. [CrossRef] [PubMed]

76. Amiri, E.; Kryger, P.; Meixner, M.D.; Strand, M.K.; Tarpy, D.R.; Rueppell, O. Quantitative patterns of vertical transmission of deformed wing virus in honey bees. PLoS ONE 2018, 13, e0195283. [CrossRef]

77. Yue, C.; Schröder, M.; Gisder, S.; Genersch, E. Vertical-transmission routes for deformed wing virus of honeybees (Apis mellifera). J. Gen. Virol. 2007, 88, 2329-2336. [CrossRef] [PubMed]

78. Posada-Florez, F.; Lamas, Z.S.; Hawthorne, D.J.; Chen, Y.; Evans, J.D.; Ryabov, E.V. Pupal cannibalism by worker honey bees contributes to the spread of deformed wing virus. Sci. Rep. 2021, 11, 8989. [CrossRef] [PubMed] 
79. Yañez, O.; Jaffé, R.; Jarosch, A.; Fries, I.; Moritz, R.F.A.; Paxton, R.J.; de Miranda, J.R. Deformed wing virus and drone mating flights in the honey bee (Apis mellifera): Implications for sexual transmission of a major honey bee virus. Apidologie 2012, 43, 17-30. [CrossRef]

80. Amiri, E.; Meixner, M.D.; Kryger, P. Deformed wing virus can be transmitted during natural mating in honey bees and infect the queens. Sci. Rep. 2016, 6, 33065. [CrossRef]

81. de Miranda, J.R.; Fries, I. Venereal and vertical transmission of deformed wing virus in honeybees (Apis mellifera L.). J. Invertebr. Pathol. 2008, 98, 184-189. [CrossRef]

82. Yañez, O.; Piot, N.; Dalmon, A.; de Miranda, J.R.; Chantawannakul, P.; Panziera, D.; Amiri, E.; Smagghe, G.; Schroeder, D.; Chejanovsky, N. Bee Viruses: Routes of Infection in Hymenoptera. Front. Microbiol. 2020, 11, 943. [CrossRef]

83. Ramsey, S.D.; Ochoa, R.; Bauchan, G.; Gulbronson, C.; Mowery, J.D.; Cohen, A.; Lim, D.; Joklik, J.; Cicero, J.M.; Ellis, J.D.; et al. Varroa destructor feeds primarily on honey bee fat body tissue and not hemolymph. Proc. Natl. Acad. Sci. USA 2019, 116, 1792-1801. [CrossRef]

84. Posada-Florez, F.; Ryabov, E.V.; Heerman, M.C.; Chen, Y.; Evans, J.D.; Sonenshine, D.E.; Cook, S.C. Varroa destructor mites vector and transmit pathogenic honey bee viruses acquired from an artificial diet. PLoS ONE 2020, 15, e0242688. [CrossRef]

85. Gisder, S.; Genersch, E.; Pfeiffer Julie, K. Direct Evidence for Infection of Varroa destructor Mites with the Bee-Pathogenic Deformed Wing Virus Variant B, but Not Variant A, via Fluorescence In Situ Hybridization Analysis. J. Virol. 2021, 95, e01786-20. [CrossRef]

86. Ryabov, E.V.; Wood, G.R.; Fannon, J.M.; Moore, J.D.; Bull, J.C.; Chandler, D.; Mead, A.; Burroughs, N.; Evans, D.J. A Virulent Strain of Deformed Wing Virus (DWV) of Honeybees (Apis mellifera) Prevails after Varroa destructor-Mediated, or In Vitro, Transmission. PLoS Pathog. 2014, 10, e1004230. [CrossRef]

87. Posada-Florez, F.; Childers, A.K.; Heerman, M.C.; Egekwu, N.I.; Cook, S.C.; Chen, Y.; Evans, J.D.; Ryabov, E.V. Deformed wing virus type A, a major honey bee pathogen, is vectored by the mite Varroa destructor in a non-propagative manner. Sci. Rep. 2019, 9, 12445. [CrossRef] [PubMed]

88. Ongus, J.R.; Peters, D.; Bonmatin, J.M.; Bengsch, E.; Vlak, J.M.; van Oers, M.M. Complete sequence of a picorna-like virus of the genus Iflavirus replicating in the mite Varroa destructor. J. Gen. Virol. 2004, 85, 3747-3755. [CrossRef] [PubMed]

89. Moore, J.; Jironkin, A.; Chandler, D.; Burroughs, N.; Evans, D.J.; Ryabov, E.V. Recombinants between Deformed wing virus and Varroa destructor virus-1 may prevail in Varroa destructor-infested honeybee colonies. J. Gen. Virol. 2011, 92, 156-161. [CrossRef] [PubMed]

90. Zioni, N.; Soroker, V.; Chejanovsky, N. Replication of Varroa destructor virus 1 (VDV-1) and a Varroa destructor virus 1-deformed wing virus recombinant (VDV-1-DWV) in the head of the honey bee. Virology 2011, 417, 106-112. [CrossRef] [PubMed]

91. Mordecai, G.J.; Wilfert, L.; Martin, S.J.; Jones, I.M.; Schroeder, D.C. Diversity in a honey bee pathogen: First report of a third master variant of the Deformed Wing Virus quasispecies. ISME J. 2016, 10, 1264-1273. [CrossRef]

92. Kevill, J.L.; Highfield, A.; Mordecai, G.J.; Martin, S.J.; Schroeder, D.C. ABC Assay: Method Development and Application to Quantify the Role of Three DWV Master Variants in Overwinter Colony Losses of European Honey Bees. Viruses 2017, 9, 314. [CrossRef]

93. Dalmon, A.; Desbiez, C.; Coulon, M.; Thomasson, M.; Conte, Y.L.; Alaux, C.; Vallon, J. Evidence for positive selection and recombination hotspots in Deformed wing virus (DWV). Sci. Rep. 2017, 41045. [CrossRef]

94. Genersch, E.; Von Der Ohe, W.; Kaatz, H.; Schroeder, A.; Otten, C.; Büchler, R.; Berg, S.; Ritter, W.; Mühlen, W.; Gisder, S.; et al. The German bee monitoring project: A long term study to understand periodically high winter losses of honey bee colonies. Apidologie 2010, 41, 332-352. [CrossRef]

95. Nazzi, F.; Brown, S.P.; Annoscia, D.; Del Piccolo, F.; Di Prisco, G.; Varricchio, P.; Vedova, G.D.; Cattonaro, F.; Caprio, E.; Pennacchio, F. Synergistic parasite-pathogen interactions mediated by host immunity can drive the collapse of honeybee colonies. PLoS Pathog. 2012, 8, e1002735. [CrossRef]

96. Di Prisco, G.; Annoscia, D.; Margiotta, M.; Ferrara, R.; Varricchio, P.; Zanni, V.; Caprio, E.; Nazzi, F.; Pennacchio, F. A mutualistic symbiosis between a parasitic mite and a pathogenic virus undermines honey bee immunity and health. Proc. Natl. Acad. Sci. USA 2016, 113, 201523515. [CrossRef]

97. Glenny, W.; Cavigli, I.; Daughenbaugh, K.F.; Radford, R.; Kegley, S.E.; Flenniken, M.L. Honey bee (Apis mellifera) colony health and pathogen composition in migratory beekeeping operations involved in California almond pollination. PLoS ONE 2017, 12, e0182814. [CrossRef] [PubMed]

98. Nazzi, F.; Pennacchio, F. Disentangling multiple interactions in the hive ecosystem. Trends Parasitol. 2014, 30, 556-561. [CrossRef]

99. Lamp, B.; Url, A.; Seitz, K.; Eichhorn, J.; Riedel, C.; Sinn, L.J.; Indik, S.; Köglberger, H.; Rümenapf, T. Construction and Rescue of a Molecular Clone of Deformed Wing Virus (DWV). PLoS ONE 2016, 11, e0164639. [CrossRef] [PubMed]

100. Ryabov, E.V.; Fannon, J.M.; Moore, J.D.; Wood, G.R.; Evans, D.J. The Iflaviruses Sacbrood virus and Deformed wing virus evoke different transcriptional responses in the honeybee which may facilitate their horizontal or vertical transmission. PeerJ 2015, 3 , e1405v1. [CrossRef]

101. Galbraith, D.A.; Yang, X.; Nino, E.L.; Yi, S.; Grozinger, C. Parallel epigenomic and transcriptomic responses to viral infection in honey bees (Apis mellifera). PLoS Pathog. 2015, 11, e1004713. [CrossRef] 
102. Boncristiani, H.F.; Evans, J.D.; Chen, Y.; Pettis, J.; Murphy, C.; Lopez, D.L.; Simone-Finstrom, M.; Strand, M.; Tarpy, D.R.; Rueppell, $\mathrm{O}$. In vitro infection of pupae with Israeli acute paralysis virus suggests disturbance of transcriptional homeostasis in honey bees (Apis mellifera). PLoS ONE 2013, 8, e73429. [CrossRef]

103. Dolezal, A.G.; Hendrix, S.D.; Scavo, N.A.; Carrillo-tripp, J.; Harris, A.; Wheelock, M.J.; Neal, M.E.O.; Toth, A.L. Honey Bee Viruses in Wild Bees: Viral Prevalence, Loads, and Experimental Inoculation. PLoS ONE 2016, 11, e0166190. [CrossRef]

104. Hsieh, E.M.; Carrillo-Tripp, J.; Dolezal, A.G. Preparation of Virus-Enriched Inoculum for Oral Infection of Honey Bees (Apis Mellifera). J. Vis. Exp. 2020, 162, e61725. [CrossRef] [PubMed]

105. O'Neal, S.T.; Brewster, C.C.; Bloomquist, J.R.; Anderson, T.D. Amitraz and its metabolite modulate honey bee cardiac function and tolerance to viral infection. J. Invertebr. Pathol. 2017, 149, 119-126. [CrossRef] [PubMed]

106. O'Neal, S.T.; Swale, D.R.; Anderson, T.D. ATP-sensitive inwardly rectifying potassium channel regulation of viral infections in honey bees. Sci. Rep. 2017, 7, 8668. [CrossRef] [PubMed]

107. Brutscher, L.M.; Daughenbaugh, K.F.; Flenniken, M.L. Virus and dsRNA-triggered transcriptional responses reveal key components of honey bee antiviral defense. Sci. Rep. 2017, 7, 6448. [CrossRef]

108. Flenniken, M.L.; Andino, R. Non-Specific dsRNA-Mediated Antiviral Response in the Honey Bee. PLoS ONE 2013, 8, e77263. [CrossRef]

109. McMenamin, A.J.; Daughenbaugh, K.F.; Flenniken, M.L. The Heat Shock Response in the Western Honey Bee (Apis mellifera) is Antiviral. Viruses 2020, 12, 245. [CrossRef]

110. Dasgupta, R.; Cheng, L.L.; Bartholomay, L.C.; Christensen, B.M. Flock house virus replicates and expresses green fluorescent protein in mosquitoes. J. Gen. Virol. 2003, 84, 1789-1797. [CrossRef] [PubMed]

111. Dasgupta, R.; Free, H.M.; Zietlow, S.L.; Paskewitz, S.M.; Aksoy, S.; Shi, L.; Fuchs, J.; Hu, C.; Christensen, B.M. Replication of flock house virus in three genera of medically important insects. J. Med. Entomol. 2007, 44, 102-110. [CrossRef] [PubMed]

112. Wang, X.-H.; Aliyari, R.; Li, W.-X.; Li, H.-W.; Kim, K.; Carthew, R.; Atkinson, P.; Ding, S.-W. RNA Interference Directs Innate Immunity Against Viruses in Adult Drosophila. Science 2006, 312, 452-454. [CrossRef] [PubMed]

113. Lingel, A.; Simon, B.; Izaurralde, E.; Sattler, M. The structure of the flock house virus B2 protein, a viral suppressor of RNA interference, shows a novel mode of double-stranded RNA recognition. EMBO Rep. 2005, 6, 1149-1155. [CrossRef]

114. Venter, P.A.; Schneemann, A. Recent insights into the biology and biomedical applications of Flock House virus. Cell. Mol. Life Sci. 2008, 65, 2675-2687. [CrossRef] [PubMed]

115. Gallagher, T.M.; Rueckert, R.R. Assembly-dependent maturation cleavage in provirions of a small icosahedral insect ribovirus. J. Virol. 1988, 62, 3399-3406. [CrossRef] [PubMed]

116. Wu, S.X.; Kaesberg, P. Synthesis of template-sense, single-strand Flockhouse virus RNA in a cell-free replication system. Virology 1991, 183, 392-396. [CrossRef]

117. Miller, D.J.; Ahlquist, P. Flock house virus RNA polymerase is a transmembrane protein with amino-terminal sequences sufficient for mitochondrial localization and membrane insertion. J. Virol. 2002, 76, 9856-9867. [CrossRef] [PubMed]

118. Miller, D.J.; Schwartz, M.D.; Ahlquist, P. Flock house virus RNA replicates on outer mitochondrial membranes in Drosophila cells. J. Virol. 2001, 75, 11664-11676. [CrossRef] [PubMed]

119. Albariño, C.G.; Price, B.D.; Eckerle, L.D.; Ball, L.A. Characterization and template properties of RNA dimers generated during flock house virus RNA replication. Virology 2001, 289, 269-282. [CrossRef] [PubMed]

120. Eckerle, L.D.; Albariño, C.G.; Ball, L.A. Flock House virus subgenomic RNA3 is replicated and its replication correlates with transactivation of RNA2. Virology 2003, 317, 95-108. [CrossRef]

121. Dearing, S.C.; Scotti, P.D.; Wigley, P.J.; Dhana, S.D. A small RNA virus isolated from the grass grub, Costelytra zealandica (Coleoptera: Scarabaeidae). N. Z. J. Zool. 1980, 7, 267-269. [CrossRef]

122. Scotti, P.D.; Dearing, S.; Mossop, D.W. Flock house virus: A Nodavirus isolated fromCostelytra zealandica (White) (Coleoptera: Scarabaeida). Arch. Virol. 1983, 75, 181-189. [CrossRef]

123. Bonning, B.C.; Saleh, M.-C. The Interplay Between Viruses and RNAi Pathways in Insects. Annu. Rev. Entomol. 2021, 66, 61-79. [CrossRef]

124. Bronkhorst, A.W.; van Rij, R.P. The long and short of antiviral defense: Small RNA-based immunity in insects. Curr. Opin. Virol. 2014, 7, 19-28. [CrossRef]

125. Gammon, D.B.; Mello, C.C. RNA interference-mediated antiviral defense in insects. Curr. Opin. Insect Sci. 2015, 8, 111-120. [CrossRef] [PubMed]

126. Wu, Q.; Wang, X.; Ding, S.-W. Viral suppressors of RNA-based viral immunity: Host targets. Cell Host Microbe 2010, 8, 12-15. [CrossRef]

127. Chao, J.A.; Lee, J.H.; Chapados, B.R.; Debler, E.W.; Schneemann, A.; Williamson, J.R. Dual modes of RNA-silencing suppression by Flock House virus protein B2. Nat. Struct. Mol. Biol. 2005, 12, 952-957. [CrossRef]

128. Lu, R.; Maduro, M.; Li, F.; Li, H.W.; Broitman-Maduro, G.; Li, W.X.; Ding, S.W. Animal virus replication and RNAi-mediated antiviral silencing in Caenorhabditis elegans. Nature 2005, 436, 1040-1043. [CrossRef] [PubMed]

129. McMenamin, A.J.; Daughenbaugh, K.F.; Parekh, F.; Pizzorno, M.C.; Flenniken, M.L. Honey Bee and Bumble Bee Antiviral Defense. Viruses 2018, 10, 395. [CrossRef] [PubMed]

130. Kingsolver, M.B.; Hardy, R.W. Making connections in insect innate immunity. Proc. Natl. Acad. Sci. USA 2012, 109, 18639-18640. [CrossRef] 
131. Kingsolver, M.B.; Huang, Z.; Hardy, R.W. Insect antiviral innate immunity: Pathways, effectors, and connections. J. Mol. Biol. 2013, 425, 4921-4936. [CrossRef]

132. Iwasaki, S.; Kobayashi, M.; Yoda, M.; Sakaguchi, Y.; Katsuma, S.; Suzuki, T.; Tomari, Y. Hsc70/Hsp90 chaperone machinery mediates ATP-dependent RISC loading of small RNA duplexes. Mol. Cell 2010, 39, 292-299. [CrossRef]

133. Dorner, S.; Lum, L.; Kim, M.; Paro, R.; Beachy, P.A.; Green, R. A genomewide screen for components of the RNAi pathway in Drosophila cultured cells. Proc. Natl. Acad. Sci. USA 2006, 103, 11880-11885. [CrossRef]

134. Galiana-Arnoux, D.; Dostert, C.; Schneemann, A.; Hoffmann, J.A.; Imler, J.-L. Essential function in vivo for Dicer-2 in host defense against RNA viruses in drosophila. Nat. Immunol. 2006, 7, 590-597. [CrossRef]

135. van Rij, R.P.; Saleh, M.-C.; Berry, B.; Foo, C.; Houk, A.; Antoniewski, C.; Andino, R. The RNA silencing endonuclease Argonaute 2 mediates specific antiviral immunity in Drosophila melanogaster. Genes Dev. 2006, 20, 2985-2995. [CrossRef]

136. Zambon, R.A.; Vakharia, V.N.; Wu, L.P. RNAi is an antiviral immune response against a dsRNA virus in Drosophila melanogaster. Cell. Microbiol. 2006, 8, 880-889. [CrossRef] [PubMed]

137. Myles, K.M.; Wiley, M.R.; Morazzani, E.M.; Adelman, Z.N. Alphavirus-derived small RNAs modulate pathogenesis in disease vector mosquitoes. Proc. Natl. Acad. Sci. USA 2008, 105, 19938. [CrossRef]

138. Maori, E.; Paldi, N.; Shafir, S.; Kalev, H.; Tsur, E.; Glick, E.; Sela, I. IAPV, a bee-affecting virus associated with Colony Collapse Disorder can be silenced by dsRNA ingestion. Insect Mol. Biol. 2009, 18, 55-60. [CrossRef]

139. Chejanovsky, N.; Ophir, R.; Schwager, M.S.; Slabezki, Y.; Grossman, S.; Cox-Foster, D. Characterization of viral siRNA populations in honey bee colony collapse disorder. Virology 2014, 454-455, 176-183. [CrossRef]

140. Niu, J.; Meeus, I.; Cappelle, K.; Piot, N.; Smagghe, G. The immune response of the small interfering RNA pathway in the defense against bee viruses. Curr. Opin. Insect Sci. 2014, 6, 22-27. [CrossRef]

141. Piot, N.; Snoeck, S.; Vanlede, M.; Smagghe, G.; Meeus, I. The effect of oral administration of dsRNA on viral replication and mortality in Bombus terrestris. Viruses 2015, 7, 3172-3185. [CrossRef]

142. Niu, J.; Smagghe, G.; De Coninck, D.I.; Van Nieuwerburgh, F.; Deforce, D.; Meeus, I. In vivo study of Dicer-2-mediated immune response of the small interfering RNA pathway upon systemic infections of virulent and avirulent viruses in Bombus terrestris. Insect. Biochem. Mol. Biol. 2016, 70, 127-137. [CrossRef] [PubMed]

143. Jarosch, A.; Moritz, R.F.A. RNA interference in honeybees: Off-target effects caused by dsRNA. Apidologie 2012, 43, 128-138. [CrossRef]

144. Nunes, F.M.F.; Aleixo, A.C.; Barchuk, A.R.; Bomtorin, A.D.; Grozinger, C.M.; Simões, Z.L.P. Non-Target Effects of Green Fluorescent Protein (GFP)-Derived Double-Stranded RNA (dsRNA-GFP) Used in Honey Bee RNA Interference (RNAi) Assays. Insects 2013, 4, 90-103. [CrossRef] [PubMed]

145. Bhatia, S.; Baral, S.S.; Vega Melendez, C.; Amiri, E.; Rueppell, O. Comparing Survival of Israeli Acute Paralysis Virus Infection among Stocks of U.S. Honey Bees. Insects 2021, 12, 60. [CrossRef] [PubMed]

146. Doublet, V.; Poeschl, Y.; Gogol-Döring, A.; Alaux, C.; Annoscia, D.; Aurori, C.; Barribeau, S.M.; Bedoya-Reina, O.C.; Brown, M.J.F.; Bull, J.C.; et al. Unity in defence: Honeybee workers exhibit conserved molecular responses to diverse pathogens. BMC Genom. 2017, 18, 207. [CrossRef]

147. Niu, J.; Meeus, I.; Smagghe, G. Differential expression pattern of Vago in bumblebee (Bombus terrestris), induced by virulent and avirulent virus infections. Sci. Rep. 2016, 6, 34200. [CrossRef] [PubMed]

148. Di Prisco, G.; Cavaliere, V.; Annoscia, D.; Varricchio, P.; Caprio, E.; Nazzi, F.; Gargiulo, G.; Pennacchio, F. Neonicotinoid clothianidin adversely affects insect immunity and promotes replication of a viral pathogen in honey bees. Proc. Natl. Acad. Sci. USA 2013, 110, 18466-18471. [CrossRef]

149. Desai, S.D.; Eu, Y.J.; Whyard, S.; Currie, R.W. Reduction in deformed wing virus infection in larval and adult honey bees (Apis mellifera L.) by double-stranded RNA ingestion. Insect Mol. Biol. 2012, 21, 446-455. [CrossRef] [PubMed]

150. Cappelle, K.; Smagghe, G.; Dhaenens, M.; Meeus, I. Israeli Acute Paralysis Virus Infection Leads to an Enhanced RNA Interference Response and Not Its Suppression in the Bumblebee Bombus terrestris. Viruses 2016, 8, 334. [CrossRef] [PubMed]

151. Erez, T.; Chejanovsky, N. Infection of a Lepidopteran Cell Line with Deformed Wing Virus. Viruses 2020, 12, 739. [CrossRef] [PubMed]

152. Genersch, E.; Gisder, S.; Hedtke, K.; Hunter, W.B.; Möckel, N.; Müller, U. Standard methods for cell cultures in Apis mellifera research. J. Apic. Res. 2013, 52, 1-8. [CrossRef]

153. Carrillo-Tripp, J.; Bonning, B.C.; Miller, W.A. Challenges associated with research on RNA viruses of insects. Curr. Opin. Insect Sci. 2015, 8, 62-68. [CrossRef]

154. Arbour, N.; Ekandé, S.; Côté, G.; Lachance, C.; Chagnon, F.; Tardieu, M.; Cashman, N.R.; Talbot, P.J. Persistent infection of human oligodendrocytic and neuroglial cell lines by human coronavirus 229E. J. Virol. 1999, 73, 3326-3337. [CrossRef]

155. Stollar, V.; Thomas, V.L. An agent in the Aedes aegypti cell line (Peleg) which causes fusion of Aedes albopictus cells. Virology 1975, 64, 367-377. [CrossRef]

156. Maringer, K.; Yousuf, A.; Heesom, K.J.; Fan, J.; Lee, D.; Fernandez-Sesma, A.; Bessant, C.; Matthews, D.A.; Davidson, A.D. Proteomics informed by transcriptomics for characterising active transposable elements and genome annotation in Aedes aegypti. BMC Genom. 2017, 18, 101. [CrossRef]

157. Wu, Q.; Luo, Y.; Lu, R.; Lau, N.; Lai, E.C.; Li, W.-X.; Ding, S.-W. Virus discovery by deep sequencing and assembly of virus-derived small silencing RNAs. Proc. Natl. Acad. Sci. USA 2010, 107, 1606. [CrossRef] 
158. Katsuma, S.; Tanaka, S.; Omuro, N.; Takabuchi, L.; Daimon, T.; Imanishi, S.; Yamashita, S.; Iwanaga, M.; Mita, K.; Maeda, S.; et al. Novel Macula-Like Virus Identified in Bombyx mori Cultured Cells. J. Virol. 2005, 79, 5577-5584. [CrossRef] [PubMed]

159. Li, T.-C.; Scotti Paul, D.; Miyamura, T.; Takeda, N. Latent Infection of a New Alphanodavirus in an Insect Cell Line. J. Virol. 2007, 81, 10890-10896. [CrossRef]

160. Ma, H.; Galvin, T.A.; Glasner, D.R.; Shaheduzzaman, S.; Khan, A.S. Identification of a novel rhabdovirus in Spodoptera frugiperda cell lines. J. Virol. 2014, 88, 6576-6585. [CrossRef] [PubMed]

161. Travanty, E.; Zhou, B.; Zhang, H.; Di, Y.P.; Alcorn, J.F.; Wentworth, D.E.; Mason, R.; Wang, J. Differential Susceptibilities of Human Lung Primary Cells to H1N1 Influenza Viruses. J. Virol. 2015, 89, 11935-11944. [CrossRef] [PubMed]

162. Chen, Y.-C.; Wang, S.-Y.; King, C.-C. Bacterial Lipopolysaccharide Inhibits Dengue Virus Infection of Primary Human Monocytes/Macrophages by Blockade of Virus Entry via a CD14-Dependent Mechanism. J. Virol. 1999, 73, 2650-2657. [CrossRef] [PubMed]

163. Lavine, M.D.; Strand, M.R. Insect hemocytes and their role in immunity. Insect Biochem. Mol. Biol. 2002, 32, 1295-1309. [CrossRef]

164. Richardson, R.T.; Ballinger, M.N.; Qian, F.; Christman, J.W.; Johnson, R.M. Morphological and functional characterization of honey bee, Apis mellifera, hemocyte cell communities. Apidologie 2018, 49, 397-410. [CrossRef]

165. Marringa, W.J.; Krueger, M.J.; Burritt, N.L.; Burritt, J.B. Honey Bee Hemocyte Profiling by Flow Cytometry. PLoS ONE 2014, 9 , e108486. [CrossRef]

166. Lanot, R.; Zachary, D.; Holder, F.; Meister, M. Postembryonic Hematopoiesis in Drosophila. Dev. Biol. 2001, $230,243-257$. [CrossRef]

167. Gábor, E.; Cinege, G.; Csordás, G.; Török, T.; Folkl-Medzihradszky, K.; Darula, Z.; Andó, I.; Kurucz, É. Hemolectin expression reveals functional heterogeneity in honey bee (Apis mellifera) hemocytes. Dev. Comp. Immunol. 2017, 76, 403-411. [CrossRef]

168. Mussen, E.C.; Furgala, B. Replication of sacbrood virus in larval and adult honeybees, Apis mellifera. J. Invertebr. Pathol. 1977, 30, 20-34. [CrossRef]

169. Annoscia, D.; Brown, S.P.; Di Prisco, G.; De Paoli, E.; Del Fabbro, S.; Frizzera, D.; Zanni, V.; Galbraith, D.A.; Caprio, E.; Grozinger, C.M.; et al. Haemolymph removal by Varroa mite destabilizes the dynamical interaction between immune effectors and virus in bees, as predicted by Volterra's model. Proc. R. Soc. B Biol. Sci. 2019, 286, 20190331. [CrossRef]

170. Tassetto, M.; Kunitomi, M.; Andino, R. Circulating Immune Cells Mediate a Systemic RNAi-Based Adaptive Antiviral Response in Drosophila. Cell 2017, 169, 314-325.e313. [CrossRef]

171. Saleh, M.-C.; Tassetto, M.; van Rij, R.P.; Goic, B.; Gausson, V.; Berry, B.; Jacquier, C.; Antoniewski, C.; Andino, R. Antiviral immunity in Drosophila requires systemic RNA interference spread. Nature 2009, 458, 346-350. [CrossRef]

172. McMenamin, A.J.; Brutscher, L.M.; Daughenbaugh, K.F.; Flenniken, M.L. The honey bee gene, bee antiviral protein-1, formerly MF116383, is a taxonomically restricted antiviral immune gene. Front. Insect Sci. 2021. in prep.

173. Milbrath, M. Varroa Mite Monitoring: Using a Sugar Roll to Identify Populations of Varroa Destructor in Honey Bee Colonies. Available online: https:/ / pollinators.msu.edu/resources/beekeepers/varroa-mite-monitoring1/ (accessed on 27 June 2020).

174. Tools for Varroa Management: A Guide to Effective Varroa Sampling and Control. 2015, p. 8. Available online: https://honeybeehealthcoalition.org/wp-content/uploads/2015/08/HBHC-Guide_Varroa-Interactive-PDF.pdf (accessed on 27 June 2021).

175. Hunter, W.B. Medium for development of bee cell cultures (Apis mellifera: Hymenoptera: Apidae). Vitr. Cell. Dev. Biol. Anim. 2010, 46, 83-86. [CrossRef]

176. de Miranda, J.R.; Bailey, L.; Ball, B.V.; Blanchard, P.; Budge, G.E.; Chejanovsky, N.; Chen, Y.-P.; Gauthier, L.; Genersch, E.; de Graaf, D.C.; et al. Standard methods for virus research in Apis mellifera. J. Apic. Res. 2013, 52, 1-56. [CrossRef]

177. Selling, B.H.; Rueckert, R.R. Plaque assay for black beetle virus. J. Virol. 1984, 51, 251-253. [CrossRef] [PubMed]

178. Marshall, D.; Schneemann, A. Specific packaging of nodaviral RNA2 requires the N-terminus of the capsid protein. Virology 2001, 285, 165-175. [CrossRef] [PubMed]

179. Yue, C.; Genersch, E. RT-PCR analysis of Deformed wing virus in honeybees (Apis mellifera) and mites (Varroa destructor). J. Gen. Virol. 2005, 86, 3419-3424. [CrossRef]

180. Boncristiani, H.F.; Di Prisco, G.; Pettis, J.S.; Hamilton, M.; Chen, Y.P. Molecular approaches to the analysis of deformed wing virus replication and pathogenesis in the honey bee, Apis mellifera. Virol. J. 2009, 6, 221. [CrossRef]

181. Ginzinger, D.G. Gene quantification using real-time quantitative PCR: An emerging technology hits the mainstream. Exp. Hematol. 2002, 30, 503-512. [CrossRef]

182. Dunnett, C.W. A Multiple Comparison Procedure for Comparing Several Treatments with a Control. J. Am. Stat. Assoc. 1955, 50, 1096-1121. [CrossRef]

183. Bauer, D.F. Constructing Confidence Sets Using Rank Statistics. J. Am. Stat. Assoc. 1972, 67, 687-690. [CrossRef]

184. Buck, K.W. Comparison of The Replication of Positive-Stranded Rna Viruses of Plants and Animals. In Advances in Virus Research; Maramorosch, K., Murphy, F.A., Shatkin, A.J., Eds.; Academic Press: Cambridge, MA, USA, 1996; Volume 47, pp. 159-251.

185. Provost, K.; Dancho, B.A.; Ozbay, G.; Anderson, R.S.; Richards, G.P.; Kingsley, D.H. Hemocytes are sites of enteric virus persistence within oysters. Appl. Environ. Microbiol. 2011, 77, 8360-8369. [CrossRef] [PubMed]

186. Wang, Y.T.; Liu, W.; Seah, J.N.; Lam, C.S.; Xiang, J.H.; Korzh, V.; Kwang, J. White spot syndrome virus (WSSV) infects specific hemocytes of the shrimp Penaeus merguiensis. Dis. Aquat. Organ. 2002, 52, 249-259. [CrossRef] 
187. Ravindran, M.S.; Bagchi, P.; Cunningham, C.N.; Tsai, B. Opportunistic intruders: How viruses orchestrate ER functions to infect cells. Nat. Rev. Microbiol. 2016, 14, 407-420. [CrossRef] [PubMed]

188. Fan, Y.; Sanyal, S.; Bruzzone, R. Breaking Bad: How Viruses Subvert the Cell Cycle. Front. Cell. Infect. Microbiol. 2018, 8, 396. [CrossRef]

189. Lamiable, O.; Arnold, J.; de Faria, I.; Olmo, R.P.; Bergami, F.; Meignin, C.; Hoffmann, J.A.; Marques, J.T.; Imler, J.L. Analysis of the Contribution of Hemocytes and Autophagy to Drosophila Antiviral Immunity. J. Virol. 2016, 90, 5415-5426. [CrossRef]

190. Chen, Y.P.; Pettis, J.S.; Corona, M.; Chen, W.P.; Li, C.J.; Spivak, M.; Visscher, P.K.; DeGrandi-Hoffman, G.; Boncristiani, H.; Zhao, Y.; et al. Israeli Acute Paralysis Virus: Epidemiology, Pathogenesis and Implications for Honey Bee Health. PLoS Pathog. 2014, 10, e1004261. [CrossRef] [PubMed]

191. Li, H.; Li, W.X.; Ding, S.W. Induction and Suppression of RNA Silencing by an Animal Virus. Science 2002, 296, 1319. [CrossRef] [PubMed]

192. Nayak, A.; Berry, B.; Tassetto, M.; Kunitomi, M.; Acevedo, A.; Deng, C.; Krutchinsky, A.; Gross, J.; Antoniewski, C.; Andino, R. Cricket paralysis virus antagonizes Argonaute 2 to modulate antiviral defense in Drosophila. Nat. Struct. Mol. Biol. 2010, 17, 547-554. [CrossRef] [PubMed]

193. Nayak, A.; Kim, D.Y.; Trnka, M.J.; Kerr, C.H.; Lidsky, P.V.; Stanley, D.J.; Rivera, B.M.; Li, K.H.; Burlingame, A.L.; Jan, E.; et al. A Viral Protein Restricts Drosophila RNAi Immunity by Regulating Argonaute Activity and Stability. Cell Host Microbe 2018, 24, 542-557.e549. [CrossRef] [PubMed] 